\title{
NO HAY MAL QUE POR BIEN NO VENGA. DEL CAOS A UN NUEVO TIEMPO ARTÍSTICO (SEVILLA, DE 1650 A 1660)
}

Fernando Quiles

Universidad Pablo de Olavide

ORCID: https://orcid.org/0000-0003-0946-3012

\section{RESUMEN}

Más allá de las secuelas demográficas y económicas, la peste de 1649 provocó importantes cambios a nivel de mentalidades. En este estudio nos ocupamos principalmente de lo ocurrido en relación con el mundo artístico, con referencia a una evolución en el sistema creativo que se produjo en apenas una década.

Palabras clave: peste negra (1649), Sevilla, barroco, mentalidad y arte, cambio artístico

\section{ABSTRACT}

Beyond its demographic and economic consequences, the Great Plague of 1649 brought about a significant change in attitudes. In this study, we deal mainly with events in the artistic world, focusing on a development in the creative system that occurred in the space of just a decade.

Keywords: the Great Plague of Seville (1649), Seville, Baroque, attitudes and art, artistic change

Estaba despierto; pero mis ideas iban poco a poco tomando esa forma extravagante de los ensueños de la mañana, historias sin principio ni fin, cuyos eslabones de oro se quiebran con un rayo de enojosa claridad y vuelven a soldarse apenas se corren las cortinas del lecho. La vista se me fatigaba de ver pasar, eterna, monótona y oscura como un mar de asfalto, la línea del horizonte, que ya se alzaba, ya se deprimía, imitando el movimiento de las olas (Gustavo A. Bécquer: Desde mi celda)

Desde la mía, abril/julio de 2020

En las páginas que siguen trato de resignificar una década que fue muy importante en la evolución de las artes sevillanas, inaugurada con una epidemia de peste negra, que tanto condicionó la vida ciudadana durante los años siguientes. El contagio diezmó la población sevillana y además desencadenó una profunda crisis social, de incalculables consecuencias. La década se inició en el abismo y al cabo de diez años todavía seguían perceptibles los estigmas. En las duras condiciones de vida, el arte, en sus distintas manifestacio- nes, fue dando respuestas a las necesidades de cada momento, en un itinerario que se prolongó hasta los sesenta. Se ha podido verificar el proceso que se dio desde la devastación del cuarenta y nueve, que sumió a la ciudad en el caos, hasta el tiempo que finalmente culminó con un nuevo arte. No es nueva la asunción de esta crisis en la evolución delas artes sevillanas, aunque sí el marco temporal, que algún especialista ha llevado incluso hasta los setenta'. 


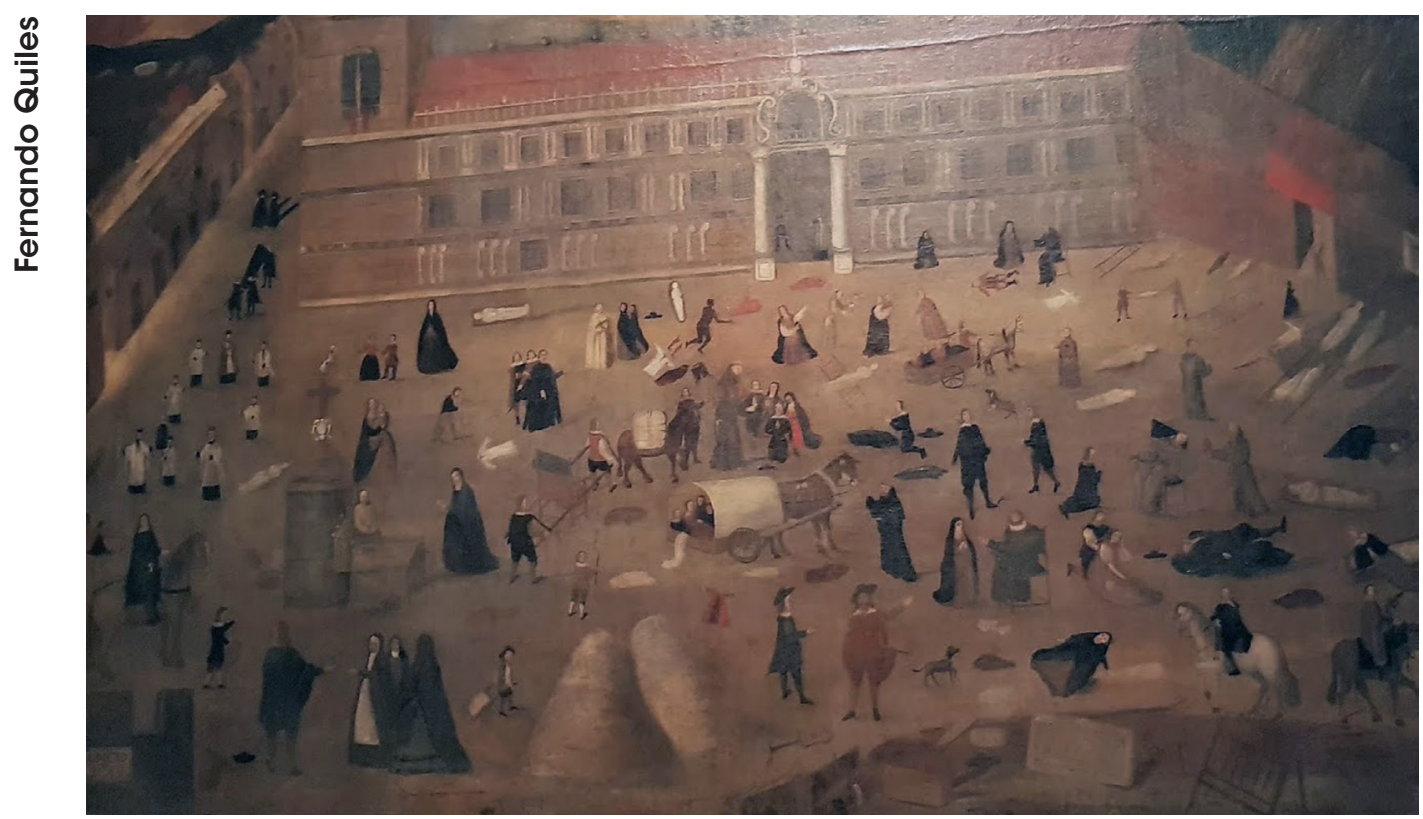

Fig. 1. Anónimo. El carnero del Hospital de las Cinco Llagas. O/l. Sevilla, Hospital del Pozo Santo, 1649

\section{De partida...}

Lo dejó escrito fray Antonio de Lorea, pero no era nuevo: "suele una enfermedad turbar el orden aun en la casa mas concertada..." mejor ilustrar este comentario, el lienzo, de autor desconocido, titulado La peste en Sevilla. Es la representación del carnero abierto ante el Hospital de las Cinco Llagas, para enterrar a los fallecidos en el lugar a consecuencia de la peste. La mortífera enfermedad se había adueñado de la ciudad, contándose por cientos los muertos diarios. Lo que arrastró al borde del abismo, tal como muestra el lienzo. No hay otra imagen, por explícita, capaz de captar el momento en que se trata de poner orden en el caos; lo que es a todas luces imposible, a la vista del reguero de inconsecuencias. $Y$ al cabo más parece un retrato de circunstancias, de la benemérita institución que luchaba enconadamente por salvar vidas y cuyo edificio preside la composición, con un heterogéneo grupo humano que acompaña a sus difuntos en el momento de la inhumación. Y así, los pocos difuntos que se diseminan por el lugar pierden en cierto modo el protagonismo frente a los vivos, que más parecen estar paseando que enfrentando una situación realmente calamitosa. En cierto modo se persigue el equilibrio entre la crudeza del relato y el freno a la impostura, en un escenario fantasmagórico. Difícil resulta observar el lienzo sin que provoque cierto desasosiego (fig. 1).

Pero el desorden se mantuvo en los meses siguientes, con la crítica situación socioeconómica que derivará del contagio. En el cincuenta y uno, una vez superado el trance, en la confianza de que no rebrotaría, "comenzaron otras penalidades, parte reliquias de la pasada por falta de gente para los empleos públicos y beneficio de los campos, y parte por esterilidad de todos frutos, que aun sin la que causó de alteración en la moneda, hubiera bastado a hacer resultar carestía de mantenimientos y hambre"s. No vamos a recrear el ambiente, contaminado por el conflicto social ocasionado finalmente por la carestía del precio del pan. Yendo del caos en la ciudad apestada, al desorden que debía ser corregido. Se buscó el camino de retorno, siendo la Iglesia la principal involucrada en ello, sobrando los indicios que muestran su actitud protectora. Amparó a la feligresía en lo que pudo. Y a riesgo de la vida de sus miembros trató de dar soluciones al problema, franqueando la entrada a sus templos y asistiendo a los enfermos. Luego, durante la revuelta urbana, abrió su granero en 
la esperanza de abaratar el coste de la hogaza de pan. El Prelado, fray Domingo Pimentel, hizo lo posible por aliviar el sufrimiento de sus fieles. Sin embargo, la calma se impondrá por la fuerza, con el ejercicio de su autoridad por parte del Asistente, quien, pese a ello, no cejó en su empeño por reconducir la situación, atenuando la necesidad de cereal. Él mismo tenía la idea de "que el total remedio consistía en enviar mucho pan", y asistido por algunos de sus colaboradores, logró hacerlo llegar a la ciudad 4 . La propia Corona ordenó a sus representantes en la ciudad -bien el juez de la Audiencia de Grados o el alcalde de su casa Cuadra-, que pugnaran por

abrir el comerçio de granos y proceder en el negoçio que de yusso en esta nra carta se hara mençion salud y graçia... [pues] nos fue hecha rrelaçion que despues que auia padesido tantas calamidades de hambre y peste y otras tan notorias y sensibles quando para su alibio esperaba una gran cosecha este preste año se le abia desbaneçido assi por los pecados del pueblo como por la maliçias del los colaboradores de los lugares de aquella prouinçia que hallandose tan sobrados con las grandes bentas que le abian hecho de los que tenian estos años por gosar aun de mayor conbenensia los abian estancado y serrado la saca en tal manera que abian subido a tan exsesibos preçios en su alhondiga que pasaban por siete ducados la fanega de trigo y tres la de çebada cossa no bista en tal tiempo y lo que mas temia era que yban creciendo... ${ }^{5}$

Aunque la ciudad quedó paralizada, pues después de la mortandad que vació barrios enteros, vivió el adormercimiento de su economía. A poco que se purguen las fuentes nos dan noticias como la referida a Francisco Lineta, quien poseía ocho tiendas con sus casas principales en la calle Francos, que estuvieron cerradas, y dos años después "todabia estan las quatro della basias por la falta de jente y comercio" $"$.

Esta crisis de subsistencia deviene en julio de 1652 en lo que se ha dado en llamar el motín de la Feria, que representa la culminación de un proceso conflictivo, que se mantuvo larvado durante años en el seno de la sociedad sevillana y estimuló la peste? ${ }^{7}$ Ortiz de Zúñiga dedica unas páginas en sus Anales para relatar cómo se produjo esta revuelta ciudadana. Una ciudad de "triste semblan-

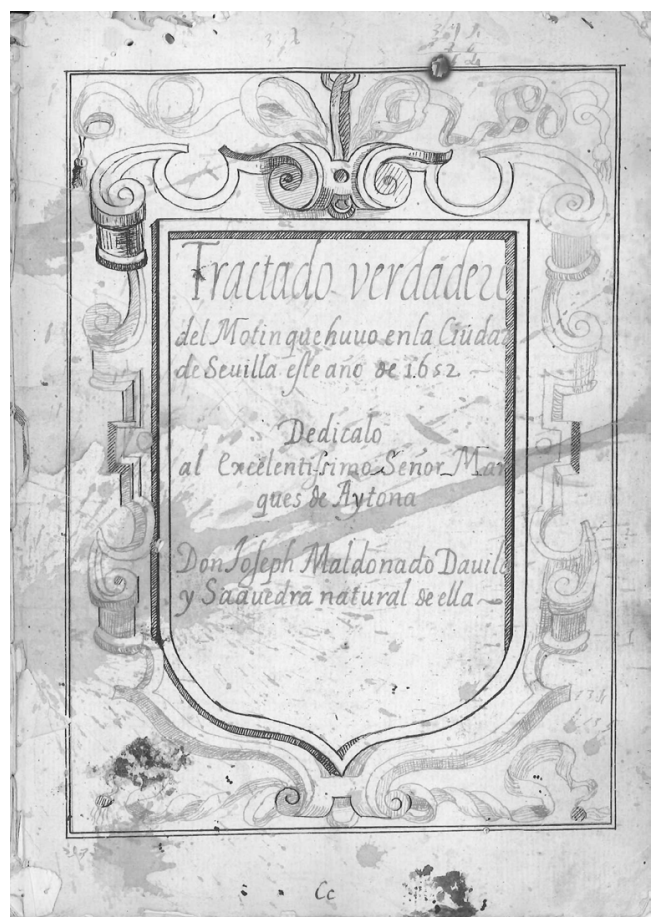

Fig. 2. José Maldonado Dávila y Saavedra. Tratado verdadero del Motín que huvo en la ciudad de Sevilla este año de 1652 (AHPS, ES.41003.AHPSE/2.1.2 // Piezas aisladas, 28796)

te... Ilena de sustos y desconsuelos", temerosa de que en el verano repitiera el brotes (fig. 2).

El motín no fue asunto menor. La ciudad sufrió intensamente los efectos sobre el cotidiano desenvolvimiento. Luis Méndez de Haro, condeduque de Olivares, aludía en carta autógrafa, dirigida a Bernardo de Valdés, a "los alborotos de la plebe" y "las inquietudes desa çiudad"s. A modo de ilustración, recordemos un caso singular y representativo a la vez. El de Juan de Villasís y Sandoval, "que murió del mucho trauajo y cansancio q tubo en el tiempo que asistio sirbiendo a Su magd en el tumulto y alboroto que vbo en esta ciud por el mes de mayo del año passado de mil y seisos y cinqta y dos asistiendo en el cuerpo de guardia Armado y con toda prebencion de que se le ocasiono un corrimto al pecho que le fue continuando hasta que murio" 10 .

Al fin no hubo más remedio que aplastar la "sedición" por la fuerza. La detención y ajusticiamiento de los líderes de la revuelta fue definitivo 


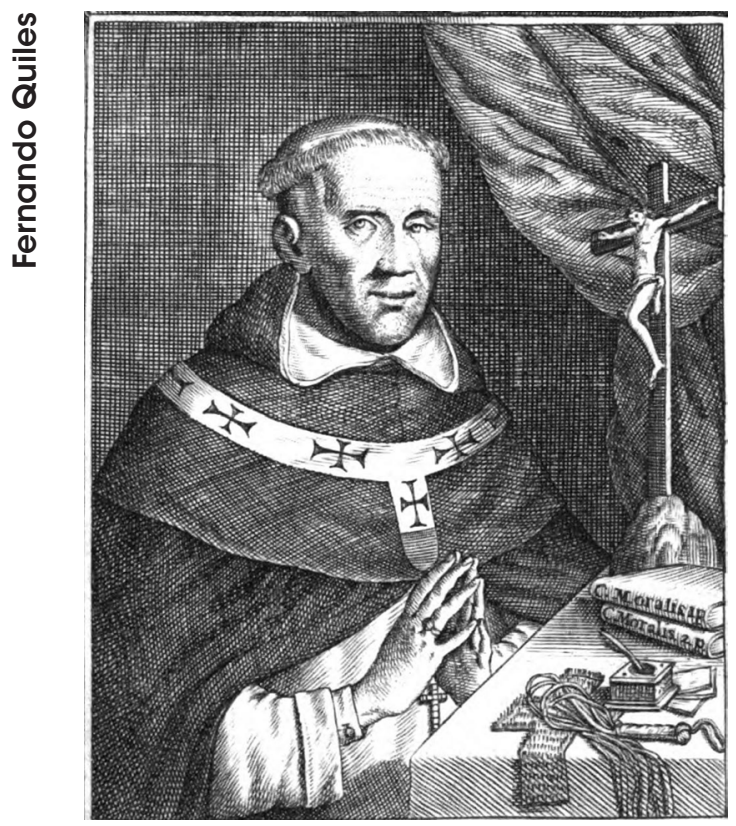

Fig. 3. Fray Pedro de Tapia. Grabado del libro El siervo fray Pedro de Tapia, de Antonio de Lorea, 1676

para concluir con el problema y empezar a superar la situación"

Volviendo sobre una de las figuras estelares del momento, que brilló en tan mortecino ambiente, el Arzobispo, cabe señalar que cumplió con su misión pastoral, en los pocos meses que ocupó la sede sevillana. Su cercanía al poder político le llevó a Roma, donde finalmente concluyó su carrera, al recibir el capelo cardenalicio de manos de Inocencio $X$, siendo sustituido en la sede sevillana por fray Pedro de Tapia, una vez normalizada la vida ciudadana en enero de 1653. El nuevo mitrado se convirtió en una figura providencial en el proceso de cicatrización de las heridas de su redil. Ortiz de Zúñiga, siguiendo probablemente a su biógrafo Lorea (1676), lo tuvo en mucha estima, reconociendo su labor meritoria, "mezclando diestrísimamente el zelo con la suavidad"12. Además, hay que celebrar la actitud de este prelado con respecto a la nueva fábrica del Sagrario, el edificio más representativo del nuevo tiempo que estamos analizando. A Tapia hay que atribuirle una parte del cambio barroco de este recinto. Él fue el primero en enterrarse en el panteón de los arzobispos ${ }^{13}$ (fig. 3).
Frente a estas comprometidas autoridades, la del Asistente, don Diego de Cárdenas y Herrera, fue poco más que irrelevante en la gestión de la crisis epidémica, ni más ni menos que otras autoridades como el Corregidor o los Caballeros Veinticuatro. Todos ellos se vieron igualmente sobrepasados por los sucesos ${ }^{14}$.

\section{Un rastro casi imperceptible}

Y si volvemos la mirada hacia nuestras figuras estelares, los artistas, todavía queda mucho por aclarar acerca de la incidencia de la peste sobre sus comunidades, así como las secuelas creativas. Personalmente, me he ocupado de los pintores que efectuaron el tránsito a un nuevo tiempo y tomaron la crisis de salud como una oportunidad para insertarse en un medio por entonces saturado. No hay cifras, pero sí referencias fiables que apuntan en la dirección de que los talleres artísticos tuvieron durante la primera mitad de la década, y a pesar de todo, alguna carga de trabajo. La peste, lejos de acabar con el sistema productivo, motivó un cambio trascendental, que he podido apenas rastrear en las fuentes documentales. La desaparición o decaimiento de viejos maestros y su sustitución por otros, jóvenes, recién examinados, que se harán cargo del refuerzo de las nuevas líneas creativas. Murillo, por edad, resistió el embate de la plaga, aunque tuvo muertos en su familia. Además se benefició de la protección del arzobispo Agustín Spínola, quien en cierto modo le facilitó el acceso al templo mayor para atender importantes encargos, siendo clave los lienzos de san Isidoro y san Leandro (1655). En la catedral tuvo la oportunidad de desarrollar un arte nuevo que se ha entendido influenciado por Herrera el Mozo. Nos faltan datos para precisar cómo fue ese giro artístico. Por ejemplo, qué hay de Francisco López, con quien compartió el encargo que el cabildo le hizo para recopilar noticia de las imágenes existentes en la ciudad de San Fernando' ${ }^{15}$. El documento que se generó en ese momento nos regala una información valiosa en relación con el sentir de los pintores de vanguardia. Aludía López, que a la sazón tenía 52 años, con diez, conoció a Vasco Pereira, alababa sus pinturas en Santa María de las Cuevas en términos tan positivos como que "eran de lo mejor que 


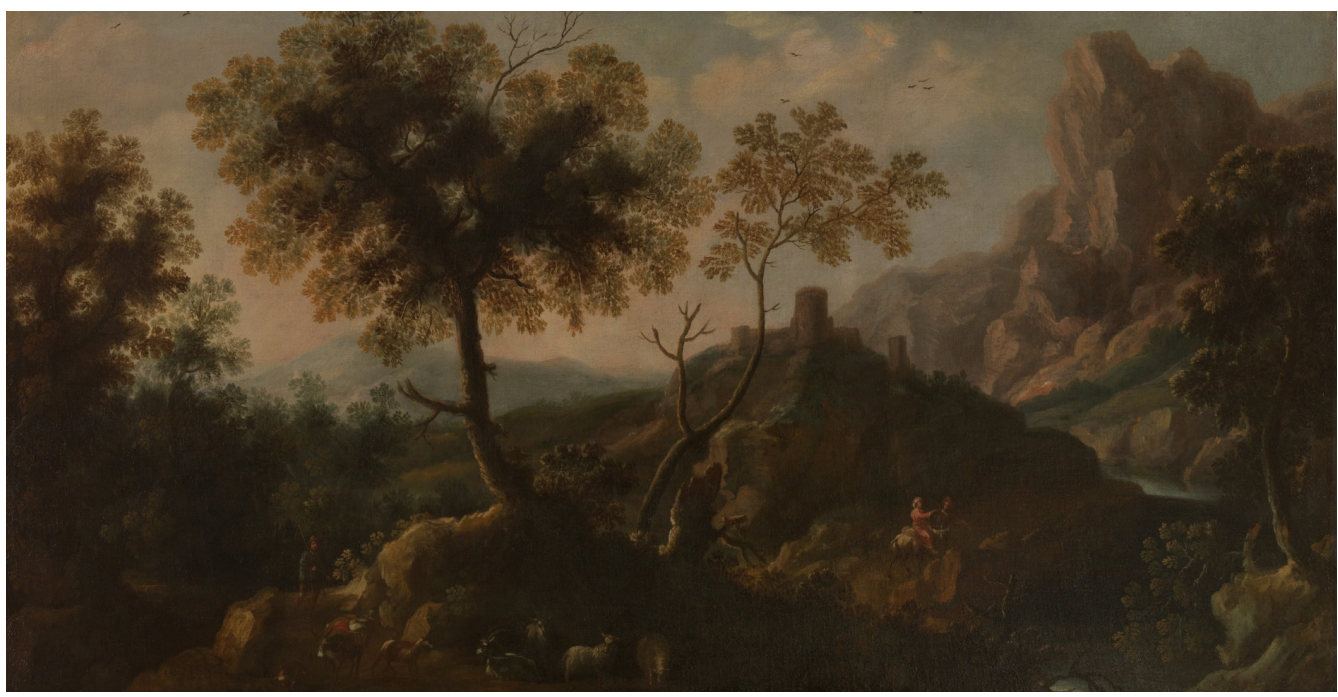

Fig. 4. Ignacio de Iriarte. Paisaje con pastores. O/I. Madrid, Museo del Prado, 1655

pintaba el dicho" ... y añadía que pintaba "siendo viejo muy diferentemente" 16 .

Al margen de estas personalidades artísticas sobradamente conocidas, fueron muchos los creadores que sufrieron en sus carnes y en sus conciencias los efectos de la peste y de la quiebra del mundo en que hasta la fecha habían vivido. Como he adelantado, el cambio generacional que se produjo dentro de la comunidad de pintores tiene su secuela en determinados signos en la evolución de la pintura local a partir del cincuenta. Sutiles cambios en temáticas, como la paisajística, tienen que ver con ello, como se ha podido verificar con el plantel de artistas recién examinados. Pero no podemos pasar por alto un detalle que, no por quedar perdido en las fuentes, dejó de tener su influencia en el orden artístico sevillano: las vivencias personales de todos y cada uno de los maestros. Valga el detalle, uno de tantos que podríamos traer a colación, el del dorador Antonio de Páez, a quien le tocó acompañar en su muerte a José Suero, siendo testigo en la declaración de sus últimas voluntades $^{17}$. Bartolomé López de Aedo falleció en la coyuntura, también tuvo que forzar una declaración testamentaria de carácter "nuncupativo", pudiendo haberse involucrado en el acto algunos de sus conocidos, como Francisco Caro, Diego de Velasco o Alonso García'8 (fig. 4).
El tiempo de crisis, iniciado en 1649, es más o menos largo, en función de los parámetros elegidos para las métricas. E igualmente su incidencia no fue igual para todas las artes. Notoria fue, por ejemplo, con relación a la producción libraria. Se ha hablado de "la decadencia material del libro" e incluso de portadas de "épocas de crisis"19.

Más abajo volveremos sobre la particular situación de la albañilería y la arquitectura, pero consideremos en este punto un detalle de respuesta necesaria a la crisis: las intervenciones "paliativas". Operaciones "quirúrgicas" sobre espacios sagrados que habrían de realizarse en la medida en que el conflicto entre las urgencias administrativas y las complacencias religiosas lo permitieran. Valga el caso que se dio en la parroquia de san Juan de la Palma, que en 1649 sufrió una importante reforma a nivel de solería, tanto en el cuerpo de iglesia, como en el coro. El maestro Alonso Ortiz de Viedma asumió la obra, que cifró en 1771 reales ${ }^{20}$. Me pregunto si estuvo motivada la intervención por la epidemia, en la necesidad de dar tierra a los hermanos de las cofradías.

Otra situación que se produjo con el fallecimiento de algunos maestros que tenían a su cargo obras, es el del traspaso o paralización de las mismas. Valga uno de tantos casos, el que se dio con el retablo del comulgatorio de san Basilio, que Juan de Torres contrató. Su viuda, María de 


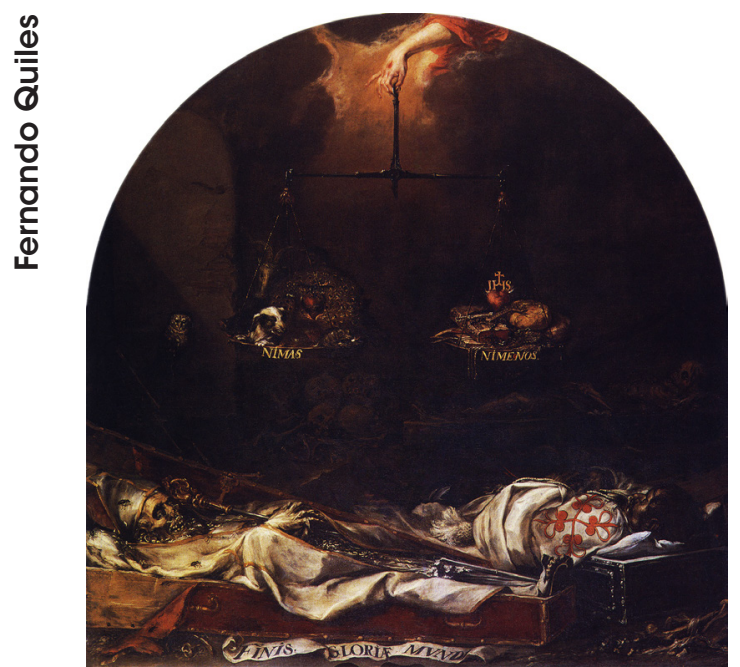

Fig. 5. Juan de Valdés Leal. In ictu oculi. O/l. Sevilla, Hospital de la Caridad, 1670-1672

la Encarnación, nuevamente casada con un zapatero, tuvo que hacer frente a la finalización de este $^{21}$. Evidentemente, quedaban fuera de lugar las estipulaciones de índole estilística. Y no fue la única obra en proceso, truncada por la peste.

\section{I/Vuelta al orden}

No hay duda del duro impacto de la peste sobre una sociedad no especialmente saludable. La mortandad fue grande, tal como se ha contado y de alguna manera se ha podido medir. La crisis económica aparejada, fue tan profunda que a punto estuvo de dejar a Sevilla fuera de este orden global en que se había situado por su lugar en la red mercantil hispana. No bien el contagio fue remitiendo se pudo ver un panorama muy negro, con una ciudad herida, en estado agónico, y en parte vacía. Lo cuentan las crónicas, que se hacen eco del vaciamiento de barrios enteros. En su momento me hice eco del recuento efectuado por orden gubernamental en tres de los sectores más perjudicados en semejante coyuntura ${ }^{22}$.

\section{¿La arboleda perdida?}

Además, la peste despertó ciertos terrores asociados a los espacios que, de un modo u otro, se relacionaron con el contagio. A modo de ilustración recordemos las cautelas que se tuvieron con los lugares que se sabían contaminados o relacionados con fallecimientos. He ahí un ilustrativo caso, el de los mayordomos de las cofradías Sacramental y de Ánimas de Onmium Sanctorum, Pedro Romero y Pedro Bermúdez, que enfrentaron una causa criminal por "desir aber abierto las bobedas de la dha yglesia donde estaban enterrados algunos cuerpos apestados" ${ }^{23}$. Y más sorprendente la cautela que hubo de tener Jerónimo de Arredondo Agüera, Contador de Resultas de Su Majestad, pues encargó dos camas de granadillo y dos espejos para remitiría a la Corte y tuvo que asegurar que "es nuevo y sin estrenar, sin hauer estado en sitio ni donde aya auido mal de contajio..." 24 .

Terrores que afloraron en múltiples circunstancias y se manifestaron también a través de las artes. De entre las múltiples referencias que se presentan como secuelas sobre las mentalidades de la época, cabe resaltar la imagen de la muerte en forma de cadáver o calavera. De alguna manera la más impactante representación cadavérica en el arte sevillano se produjo de la mano de un artista que había sufrido las consecuencias de la peste, Valdés Leal, a instancias de un encargo promovido por un patrono que tampoco pudo superar las vivencias personales, Miguel de Mañara. En sus dos famosas vánitas, In ictu oculi o Gloriae finis mundi, juega con el esqueleto como prefiguración de la muerte como alegoría, pero también con los cadáveres en sus ataúdes, envueltos en sudarios y con los insectos iniciando su tarea. No faltan antecedentes en la configuración de estas obras, bien que en la base habría que considerar la travesía del 49 (fig. 5).

Y hablando de imágenes de muertos, ¿qué decir del lienzo del carnero de las Cinco Llagas? ¿quién y por qué se hizo este relato visual? Una vista caballera de la fantasmagórica situación, de lóbrega pintura, de tintas que refuerzan un celaje con nubes que más parecen el humo que anuncia un incendio. Los cadáveres, envueltos en sus sudarios, se reparte por doquier, diseminados entre los grupos humanos. Como he avanzado, resulta una imagen poco menos que desconcertante, por cuanto los vivos se desenvuelven con una naturalidad inapropiada en el lugar y el momento.

Y frente a esta extravagante interpretación de un entierro comunitario, otro retrato de ciudad 


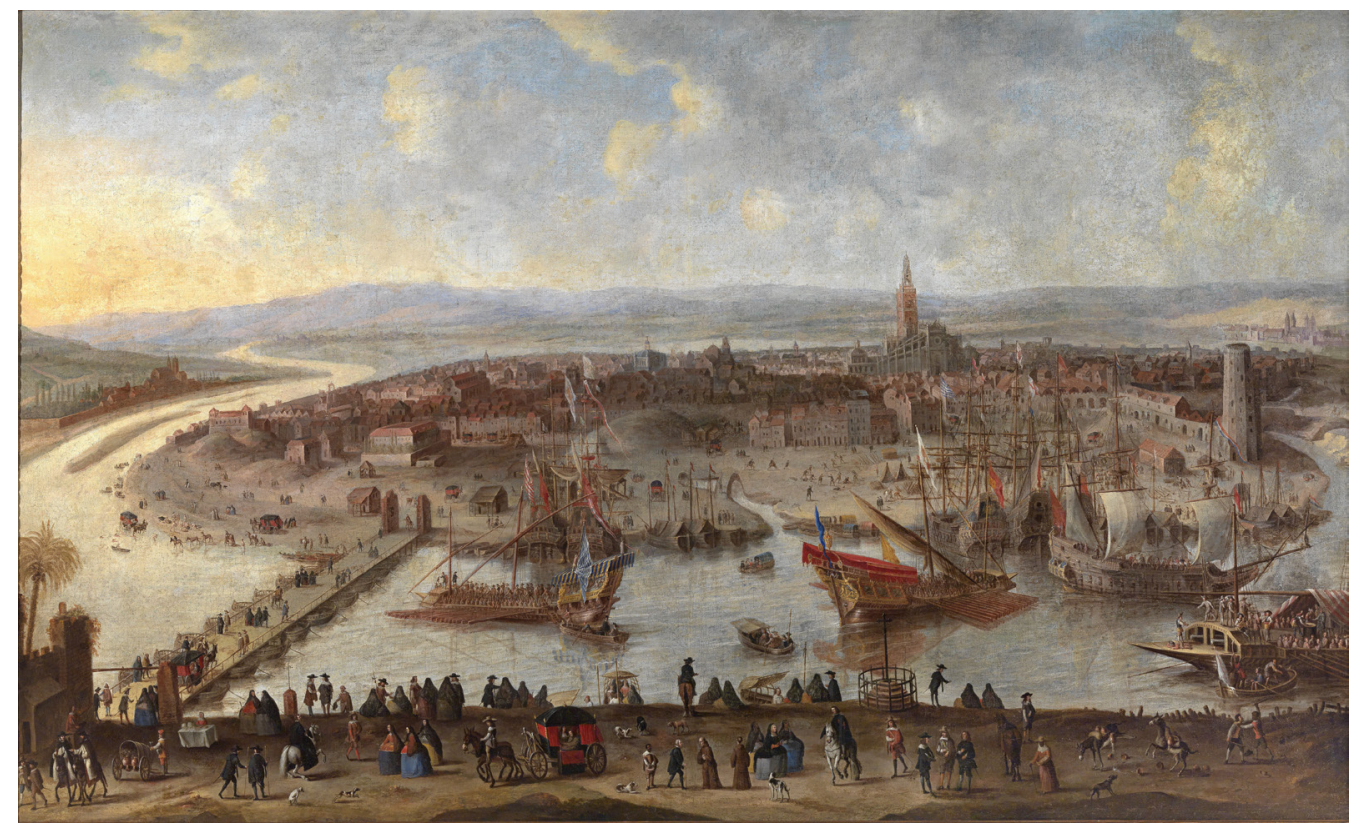

Fig. 6. Anónimo. Vista de Sevilla. O/l. Sevilla, Fundación Fondo de Cultura, h. 1660

realizado algunos años -quizás meses- después, que en cierto modo no se encuentra libre de los efectos de la peste. Me refiero a la vista del puerto de Sevilla y que pertenece a la colección Focus (fig. 6). Y, al margen de la divergencia cualitativa entre ambas obras, muy superior en el segundo de los lienzos, hay que poner la atención en otra instantánea que habla de un orden que, supuestamente, se ha trastocado con la crisis del 49: el económico. La principal fuente de riqueza de la ciudad se presenta a través de este cuadro, pero también una galería de tipos humanos, que se exhibe orillando el escenario principal, a modo de retrato colectivo. Se ha dicho que la obra pudo haber sido realizada por un artista holandés, a expensas de algún agente comercial extranjero, que ante todo quiso tener un retrato de tan importante puerto ${ }^{25}$. En cierto modo, se trataba de recuperar la imagen de una arboleda, en metafórica alusión a los palos de los navíos. En las fechas en que pudo realizarse esta obra, Sevilla pierde relevancia al lado de Cádiz, en relación con el tráfico colonial. Sin embargo, no son pocos los holandeses en ella establecidos con tratos comerciales, algunos tan conocidos como Josua van Belle o Gaspar Pluyms 26 .
La comparación con las fuentes grabadas, las vistas de Mathäus Merian y de Rombourt Van den Boyen (fig. 7), en las que se han visto las bases de composición y representación, evidencia dos detalles significativos: ante todo, la presencia de embarcaciones que siguen unas pautas muy similares, entre las que se alinean embarcadas y las que transitan por el río, bien de llegada o de salida. El Arenal siguió siendo el sostenedor de la vida económica de la ciudad. Y las fuentes alternativas a las propias de Indias, hacen pensar en la continuidad del flujo de plata a la ciudad pasada la mediación de siglo27. Pero al fin el fraude se impone, con el consiguiente ocultamiento de información precisa en los registros de entrada de bienes. Para la década de los setenta, cobra sentido el comentario de un viajero asiduo, el carmelita fray Isidoro de la Asunción, que llega a decir: "todos los cargadores y los que pasan en la flota procuran ocultar cuando pueden y pasarlo sin pagar derechos; y es mucho más de lo que importan los indultos" 28 .

Mucho se ha escrito sobre la ciudad que puso a prueba su resiliencia durante el contagio, y que llegó a la quinta década del siglo mermada en su pujanza económica. Y aun así tardaría en perder 


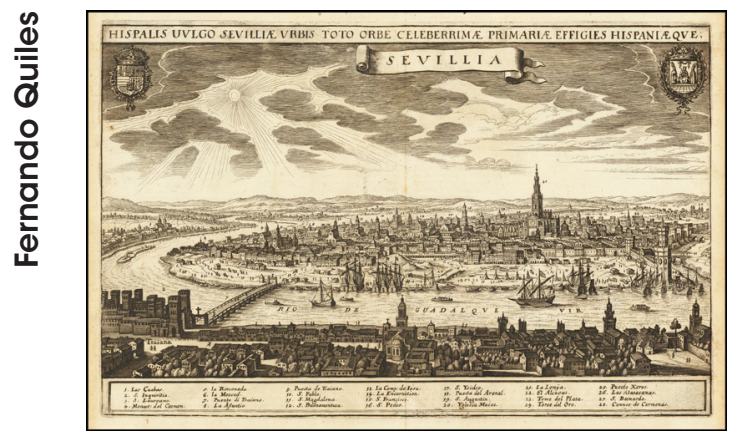

Fig. 7. Mathäus Merian. Hispalis vulgo Sevilliae urbis toto orbe seleberrimae primareae effigies Hispaniaeque. Talla dulce. Frankfurt, 1683

su esencia, que la convirtió en una nueva Babilonia, tal como Lope de Vega cantó:

Eso hay en el Arenal,
¡oh, gran máquina Sevilla!
¿Esto sólo os maravilla?
Es a Babilonia igual29

Una idea que sedujo a Miguel de Mañara, si bien volvió sobre el parangón con un sentido más amargo, al reconocer en su testamento, al final de sus días, haber servido "a Babilonia"30. En efecto, esa Babilonia que había podido conocer desde su juventud $y$, sobre todo, contemplarla desde la institución donde se refugió, el hospital de la Caridad, que se erigió a la sombra de las atarazanas y con puerta al Arenal.

El caso de Mañara es relevante, por demás, dada su posición en la ciudad y su evolución personal, que refleja en cierto modo lo que ocurrió con el conjunto de la población. Se le ubica en el ámbito público ya en 1649, con sólo 22 años. Vinculado, entonces, al Concejo y la Universidad de Mercaderes. Además, de tener una posición de privilegio dentro de la Orden de Calatrava ${ }^{31}$. Desde 1655 figura como miembro de las juntas del Consulado, por lo que fue comisionado a la Corte un año más tarde, retornando en 1658 como caballero Veinticuatro, en representación de la ciudad para felicitar el nacimiento del príncipe Felipe Próspero. Pero tan brillante trayectoria quedó frustrada con el fallecimiento de su esposa, en septiembre de 1661. A consecuencia de ello sufrió un proceso introspectivo que le llevó, finalmente, a encarnar el espíritu de la cultura barroca tal como se manifiesta en su propia obra, la iglesia del hospital de la Caridad ${ }^{32}$.

Una década para curar heridas y restituir el orden

La década de los cincuenta, sobre todo en su primera mitad, transcurrió salpicada por el brote de peste, la carestía económica y el posible extravío de los artistas en su nebulosa creativa. En la práctica fue un tiempo dedicado a la cura de heridas y de retorno a una normalidad que quizás no llegara como se esperaba. Todavía en el verano de 1650 se temía la reproducción del brote. Y aún en el cincuenta y cinco no eran pocos los pintores que pugnaban por abrir tienda en un mercado que podría estar desarticulado. Al respecto son muchos los matices que permitirían cambiar nuestra visión de esa realidad. Una realidad que a través del parco relato notarial pudiera parecer de retorno a la cotidianeidad previa al contagio, aunque una mirada crítica genera dudas, pues permite sospechar que pasarían años antes de que ello ocurriera.

Al arzobispo Pedro de Tapia le tocó en suerte arreglar las costuras de la lacerada piel sevillana. Su indomable espíritu derrochó generosidad al punto de no buscar otra cosa que el beneficio de los necesitados, poniendo mucho cuidado incluso en favorecer a las mujeres. Lorea, que conocía bien esta actitud, dijo: "Buscaba con sus limosnas el remedio de la necesidad, no su crédito, ni sustentar con ellas a olgaçanes, quando sobran tantos en todas partes, padeciendo calamidades, y miserias" ${ }^{33}$.

Don Pedro era dominico, poco dado a la ostentación y la alharaca, pero sintiendo como obligación asistir a su rebaño más menesteroso. En él encontró su mejor aliado para dar cumplimiento a sus compromisos con la fábrica catedralicia Alonso Ramírez de Arellano. Ante todo, logró de su munificencia el aporte de veinte mil ducados que, con otros tantos había aportado su antecesor, permitió rematar al fin la fábrica del Sagrario, que llevaba décadas en un proceso constructivo iniciado décadas antes, con don Pedro de Castro ${ }^{34}$. De quien le precedió en la sede, Pimentel, supo de los beneficios del trato directo con los fieles. Llegó a decirle, de cara a sus visitas pastorales, que cambiara de actitud con relación 


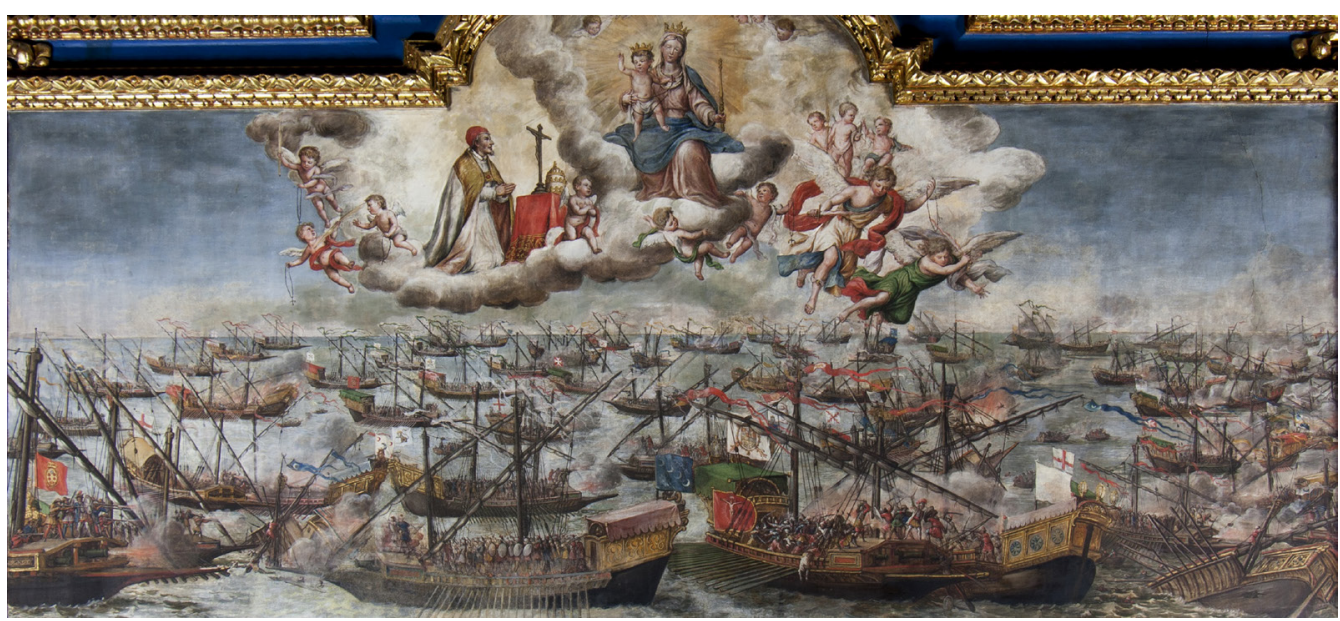

Fig. 8. Lucas Valdés. La Virgen del Rosario preside la batalla de Lepanto. O/I. Iglesia de la Magdalena, 1709-1715

a ellos, "que mudase de traje, pues venia a tierra más distinta, que distante, pues la umildad que era de exemplo en Castilla, seria de poca estimacion en Andalucía, donde era menester portarse conforme al natural de la Prouincia" ${ }^{35}$. Recomendaciones que siguió en el cumplimiento de su ministerio en la primavera de 1654.

\section{El bálsamo espiritual}

La Iglesia que había sido muy diligente y activa en plena crisis, cediendo espacios, dando sustento y confortando anímicamente, empujó desde distintos ámbitos la renovación de ciertas formas de culto mayoritarias, sobre todo, el Rosario y la Inmaculada, sin olvidar el culto universal a San Fernando. El proceso de reivindicación de la imagen de Fernando como santo, en que se involucró Murillo, se frustró con la peste. Sin embargo, se siguieron moviendo los hilos de la causa, al punto de que en 1655 Roma asumió el culto inmemorial del santo rey.

La terrible coyuntura se hizo notar en la reorientación de valores sociales. El sentimiento de ser tan vulnerables y no tener una defensa física frente a la acometida del agente contaminante, dio más sitio a la religiosidad más recalcitrante. Prácticas religiosas impregnadas de pietismo, respuesta a veces incontrolada en semejante situación ${ }^{36}$. En algún caso con miradas al pasado, como la celebración de la batalla de Lepanto, como hizo la hermandad de la Oración en el Huerto, del colegio dominico de Montesión, en octubre de 1656, pintando para la ocasión un anónimo pintor -que se ha pensado era Murillounas sargas ${ }^{37}$. Sin saber cómo se concretó semejante escenario naval, cabe pensar en referentes que por entonces circulan por algunos centros artísticos españoles, como Toledo. En nuestra ciudad tenemos un modelo más tardía de Lucas Valdés, que en a la postre es una recreación de poder naval hispano (fig. 8).

El estímulo al culto sacramental es una de las más claras manifestaciones de esta nueva sensibilidad postraumática. A principios de 1651 Miguel Cid contribuye a la exaltación eucarística con la fundación de una fiesta en San Martín ${ }^{38}$ y otra en Omnium Sanctorum ${ }^{39}$. Sin embargo, fue el dogma de la Inmaculada Concepción el que más vibró en el corazón de los sevillanos. El estímulo al culto concepcionista es notorio en los primeros años de la década. La demanda espiritual tras el contagio creció a instancias de los franciscanos y de un meritorio fraile, fray Juan de Quirós, siendo Murillo el gran intérprete de la matriz artística, que fijó en un lienzo, el mismo que presidió la iglesia conventual a partir del verano de $1651^{40}$. Asimismo, otros personajes tomaron parte en la empresa, como el duque de Arcos, que llevó a reclamar al gran artista para que le hiciera un trabajo en su villa, Marchena. Y aun cuando no ha podido verificarse cuál fue la encomienda de 
los Ponce de León, se ha pensado que podría ser la que guarda hoy en día el Louvre ${ }^{41}$.

\section{La ficción como itinerario}

Al fin, el arte da continuidad de este trastoque y respuesta a una nueva inquietud comunicativa. El abanico de posibilidades que se abre a partir de estas ansias expresivas, se manifiesta en todos los ámbitos de la creación artística y literaria. Y en este sentido considero fundamental el lugar ocupado por el mundo del teatro. Y, sin embargo, a la luz de los documentos, los corrales dejaron de ser escenarios para la comedia y lo fueron en exclusiva para la tragedia. Las cifras de muerte en estas viviendas colectivas fueron elevadísimas ${ }^{42}$. A pesar de ello, todo apunta a que, aun en plena crisis epidémica, los autores de comedias y los actores y las actrices, siguieron dando muestras de la vitalidad de este arte. No faltan referencias documentales a acuerdos laborales entre autores y compañías para seguir con la actividad, incluso en el vórtice de la epidemia. Igual es una clara muestra de la vitalidad del teatro, como la necesidad de afrontar la crisis de vida con una ficción alternativa. En el verano del cincuenta el autor de comedias Francisco de Castro acordó con José Rafael, a cuyo cargo estaba el corral del Coliseo, efectuar cuarenta representaciones ${ }^{43}$. El contrato especifica que en modo alguno se habría de actuar en la Montería, lo que pone de manifiesto el hecho de que seguía siendo un lugar alternativo muy popular. Así lo reflejan los documentos, los mismos que aluden al éxito de convocatoria tras de la epidemia. La Corte está en el horizonte de varias de las compañías teatrales. Recordemos el caso de Luis López, autor de comedias, quien en septiembre de 1652 realiza una "gira" por Córdoba y la Corte . $^{44}$

La capacidad transmisora del teatro es indudable. Y así, contrariamente a lo ocurrido dos décadas más tarde, la comedia llegaría a ser celebrada por la propia Iglesia. No de otro modo se explicaría el hecho de que la orden de san Juan de Dios, en su convento hospital de la Misericordia de Cádiz, contratara al autor de comedias Pedro de la Rosa, para que con su compañía representara treinta comedias diferentes ${ }^{45}$. El parentesco de este arte dramático con el arte de la representación litúrgica, de manifiesto en los autos sacramentales, está claro y la conectividad es plena ${ }^{46}$.

\section{Oratoria y narrativas barrocas}

El teatro es mucho más que Calderón y el Coliseo madrileño, más que la Montería y los pasacalles del Corpus. Es un arte "total", que incluso traspasó los muros del ámbito sacro. Con toda clarividencia lo expuso Juan de Zabaleta, en El día de fiesta por la tarde (Madrid, 1660):

Quien hubiera gustado de un Templo sin gente podrá decir quán celestiales gustos están allí escondidos... Si alça los ojos a los Altares verá las Imágenes de muchos Santos; quédese mirándolos a ellos en ellas, y ellos con la acción en que están figurados representan vivisimamente muchas de sus virtudes. El templo se vuelve teatro y teatro del Cielo. No entiende bien de teatros quien no dexa por el Templo el de las Comedias ${ }^{47}$

$Y$ es que en los templos también se dramatizó, siendo uno de los ámbitos primordiales de esta teatralidad sacra, el púlpito, donde el orador despliega su talento persuasivo y su capacidad comunicativa. Y así la retórica que en este siglo se "literaturiza", tanto por la "densidad conceptual" como por el desarrollo del "ornato". Los jesuitas, conocedores de las ilimitadas posibilidades de la oratoria, despliegan todo un arte que se ha sintetizado en estos términos:

Es cierto que la oratoria de este siglo insiste mucho más en la ilustración deleitosa, en la sensibilización y en sentimentalización de los mensajes que en la fuerza persuasiva de los argumentos racionales para doblegar la voluntad. Se trata, en definitiva, de una actitud muy barroca que pretende impresionar $y$ mover deleitando, persuadir más que de convencer desde con pruebas racionales ${ }^{48}$.

Llevando a lo límites este arte expresivo, fray Luis de Granada puso las bases de la teoría de tonos, para que la desarrollara el padre Escardo, que llegó a dar indicaciones sobre las destrezas del predicador, explicando que "De la voz que ha de usar el predicador en cada parte del sermón, ó de los Tonos, y de que vicios se ha de guardar en la pronunciación" 49 . Al fin la conexión entre la oratoria y el arte se hizo precisa, porque fortalecía el mensaje o bien permitía su pervivencia en el tiempo. Además era preciso conjugar el riesgo 
que entre un público adocenado tenía la repetición de los sermones con el fin de facilitar la asunción de la palabra de Dios. Y así "la predicación, en términos de "retórica sacra", encontró su última vía de sobrevivencia en el arte"

Esta teatralización de la liturgia, con la que el fiel es espectador, puede estar en la base de la reducción de los sermones impresos durante la segunda mitad del XVI|ls1.

Un nuevo orden artístico, con el agotamiendo de un sistema

Quizás sea el retablo donde mejor se pone en claro la respuesta artística a una necesidad expresiva y conceptual. El sistema tetrástilo contribuyó a organizar el relato bíblico o hagiográfico en los altares mayores de las iglesias. Se atribuye a Felipe de Ribas la aportación más genuina de la retablística de mediados de siglo. El retablo mayor de los mercedarios, de 1646, es novedoso. Dabrio resalta que con esta obra "el arquitecto dará un paso hacia adelante, al concebir una estructura de gran tamaño articulada por un orden gigante de columnas, que presentan como novedad el fuste saIomónico, utilizado en Sevilla antes de ahora sólo con carácter decorativo, pero no estructural" ${ }_{52}$.

El salomónico podría ser el signo del nuevo tiempo. Se ha considerado el retablo mayor de la Cartuja de Jerez de la Frontera, construido entre 1636 y 1639 con traza de Alejandro de Saavedra, aunque se ha sugerido que pudo ser el flamenco José de Arce, que se ocupó de la labor escultórica, quien pudo motivar la introducción de ese elemento en la nueva arquitectura en madera. Su paso por Roma bien podría justificar esa influencia53. También se tiene a Cano como otro de los introductores del salomónico. Valgan sus dibujos sobre la "Puerta Salomónica" o el detalle de retablo con columnas "tuertas" 54 . En este sentido habría que al menos sospechar en la "conciliación" ideológica entre un conjunto de artistas que coincidieron en tiempo y lugar, entorno al retablo nuevo y a mediados del XVII. A Saavedra se le ha atribuido la paternidad del primero de los retablos salomónicos en el antiguo reino sevillano. Tuvo a su lado a Arce. En la catedral vieja de Cádiz coincidió con el escultor Alonso Martínez y Juan Gómez Couto, dorador, quien a su vez trabajó con Martín Moreno. Y al fin el vínculo con
Felipe de Ribas y, lo más importante, la relación de maestro-discípulo entre Saavedra y Bernardo Simón de Pineda (1651). Un desarrollo que involucra la periferia sevillana, como a la sazón eran ambas ciudades gaditanas.

Con todo este debate formal no podemos pasar por alto los condicionantes expresivos. Hay quien ha observado que hacia 1650 se produce un cambio, con un "desinterés argumental" y un "reforzamiento elocutivo". Un reforzamiento del adorno como forma de persuasión, con un juego en la disposición de los nichos, desajustados los centrales respectos de los laterales como forma de dinamizar la lectura. Al fin la lectura de esos libros abiertos sigue dando sentido a la trama organizativa del retablo ${ }^{55}$.

Martín González hacía otra interpretación en la manera de conducir la lectura en el retablo, al considerar la ruptura de la horizontalidad en la disposición de los cuerpos, que refuerza el barroquismo en los retablos ${ }^{56}$.

Y con el retablo el conjunto de las artes involucradas. La arquitectura que se plantea como mero estructurador de contenidos, para facilitar la lectura del repertorio hagiográfico. Hasta tanto no se adopte las nuevas estructuras de altares con baldaquinos, de la mano de Pineda, estas construcciones no son más que una amalgama de piezas, obra de artífices de muy diversa formación. En este punto resulta cuando menos significativo resaltar el papel jugado por los pintoresdoradores. La policromía implica una operación global, que atañe tanto a las estructuras como a los elementos figurativos, cuando no el muro inmediato, pero también una actividad parcial, diferenciado elementos arquitectónicos, de los decorativos y los figurativos. Todavía a principios de la década de los cincuenta, se contratan operaciones parciales sobre las esculturas. Como nos descubre el acuerdo firmado por Francisco de Fonseca, con el convento de Santa Clara de Carmona, "el estofar, dorar y encarnar nueue cuerpo de santos y seis niños y dos tarjas para el retablo del altar mayor del dho convto que los seis niños y dos tarjetas se conputaron por dos cuerpos" ${ }^{57}$. 


\section{Paradigmas constructivos e inercia funcional}

Un pequeño detalle que testimonia cómo en la década de los cincuenta, la ciudad ha de recuperar su equilibrio, con medidas paliativas, algunas puramente epidérmicas, otras de índole estructural. Revertir la situación implicó al conjunto de los poderes públicos, tanto civiles como eclesiásticos. En el ámbito constructivo, más allá de intervenciones que devolviera la confianza a los ciudadanos hacia los espacios públicos, de los que huyeron para ponerse a salvo y que algún día habrá que analizar, cabe destacar la renovación de la Cárcel Real. Después de la profunda reforma que hizo Pedro Sánchez Falconete del viejo recinto hay que recordar la operación efectuada entre 1659 y 1660 por Pedro del Valles8. Evidentemente los conflictos urbanos recientes aconsejaron a los responsables de la institución su mejora.

El Sagrario fue una empresa artística de la mayor relevancia, en que se involucró el cabildo y especialmente algunos próceres locales que comprometieron su persona y dinero, para refuerzo del culto a la Inmaculada, las fiestas asociadas, más luego la adecuada conformación del espacio interior en que tomaron parte artistas que habrían de situarse en la vanguardia artística, como José de Arce, que en 1657 realiza las ocho bultos que se apoya en el antepecho de la tribuna, con la que se trata de renovar una arquitectura que en 1652 no deja de ser anticuada. Un proyecto inicial manierista de Juan de Zumárraga, que respetaron con fidelidad sus seguidores ${ }^{59}$.

Por último, llamo la atención sobre la pervivencia del teatro y los corrales de comedia. En la primavera del cuarenta y nueve fueron cerrados e incluso cancelados los autos sacramentales del Corpus. Y sin embargo no había acabado el año, sin que pudiera garantizarse la seguridad del público, cuando se autorizó la apertura del corral de la Montería. Hasta cinco representaciones fueron permitidas. Sin embargo, ante el evidente riesgo para los espectadores, la Junta de Salud obligó a cancelar los espectáculos ${ }^{6}$.

Regenerando los talleres artísticos, frente a una demanda aminorada

La regeneración del taller de pintura, que he podido en cierto modo ilustrar a partir de las fuentes notariales, se produjo principalmente por la incorporación de nuevos artistas en un número superior a lo que habitualmente ocurría, según las necesidades de taller. No voy a entrar en detalle sobre las prácticas de taller que llevaron a esa renovación, principalmente los exámenes de maestro, pero sí quiero retornar a las conclusiones de aquellos estudios previos. Algunos de los nombres de los nuevos titulares de taller han sido identificados incluso con una producción artística, como Ignacio de Iriarte, que provocó un importante cambio en la evolución del paisaje. De Llanos y Valdés, quien había enviudado en tan aciaga circunstancia, se conoce la macabra serie de cabezas cortadas, aunque son más tardías, cabe pensar en una corriente creativa dramática, en la que se incluye el conjunto de su obra, con especial relevancia de obras con el San Jerónimo del Museo, que apoya su libro en una calavera.

En principio, la renovación del taller se produjo con el ingreso de una numerosa serie de nuevos pintores, que se examinaron en los años que siguieron al de la peste ${ }^{61}$. No obstante, quienes lideraron la escuela fueron los maestros de las dos generaciones anteriores que habían logrado salvarse del contagio. El papel de Murillo, por diversas circunstancias, será capital a partir de ahora. No obstante, algunos de los neófitos también lograron situarse en el mercado con reconocimiento de su producción.

Curiosamente, las circunstancias sobrevenidas dieron al traste con el orden gremial y se dieron situaciones tan anómalas, como la que refiere un documento de 1651. Se trata de la cancelación de un contrato de aprendizaje establecido entre el maestro Alonso de Zamora y el iniciado Tomás Toledano. El acuerdo, firmado en 1646, concretaba un tiempo de formación de siete años. Y a falta de los dos últimos, se decidió dar por finalizado el periodo de aprendizaje, al haber cumplido con una ardua tarea creativa, algo que no ha trascendido en otros casos: "Consentia y conss $^{\circ}$ quedandole el dho aprendiz çiento y beinte lienços pintados como le ordenare de a dos baras o dos baras... cada uno acauados en toda perfecçion acauados a satisfaçion suia luego que de acauados los dhos ciento y beinte quadros a de ser y qdar libre como si berdadermte se obiera acauado los dhos siete años" "2. Quizás no se 
trate de un acuerdo de obra en compensación por el tiempo de aprendizaje, sino más bien una propuesta para medir el proceso de formación, el tiempo dedicado a la tarea.

No hay estudios sobre la demanda artística tras de la peste. Evidentemente hubo de resentirse, con la reducción poblacional, pero también con el cambio de sensibilidad. Sería interesante volver sobre ella para tratar de explicar la evolución del arte en esta década. Hasta qué punto esa demanda condicionó la producción de los artistas.

Ante todo, cabría considerar el fallecimiento de algunos promotores, con lo que probablemente hubo de producirse mermas en los pagos, pese a las garantías legales. Quizás fuera la razón de que un artífice tan popular en la época con Blas de Escobar, a quien se le confieren diversos contratos en la fecha, como el retablo principal de los mercedarios gaditanos, tuviera que pedir prestado a su colega Alfonso Martínez hasta 158 pesos y medio63.

A nivel de escultura he podido conocer cómo en el tiempo de la peste y meses sucesivos, la mortandad dejó muchos encargos sin entregar. En abril de 1654 el escultor Manuel de Morales dejaba expuesto en su testamento la situación personal vivida a raíz de la epidemia, con varias obras realizadas a demanda de su clientela y que en algún caso no logró cumplir por fallecimiento ${ }^{64}$. La venta en tienda, más habitual de lo que se refiere en las crónicas, pudo verse muy perjudicada con esta dramática coyuntura. Y de otro lado, muchas de estas obras menudas que transitaban por esta vía comercial, acabado su itinerario en los ámbito conventuales y eclesiásticas, cuya relevancia se hizo notar, al contrario de lo que ocurrió en otros ámbitos de la privacidad.

Algunos pintores aprovecharon la coyuntura para separarse del maestro y poner tienda propia, como ocurrió con Juan Rodríguez Mejía quien planteó el examen como el modo de poner orden en su situación profesional: "Digo que yo a muchos años que uso el arte de la pintura y por la estrechesa de los tiempos no he podido de examinarme y atento a mi mucha pobreza suplico a Vsa sea servido a darme licencia para usar el dicho arte por el tiempo que Vsa fuese servido en que recibiere merced de su grandeza" ${ }^{65}$. Sin embargo, por otro escrito, presentado por Luis de Silva al cabildo secular, en el verano de 1676, tenemos noticias de la actitud coercitiva de los del oficio con quienes ejercían sin título: "Para sustentarme y a mi mujer y dos hijos trabajando en el oficio de pintor haciendo algunos cuadros o floreros que me encargan y es así que por los veedores del dicho oficio me han hecho y me hacen muchas extorsiones y amenazas de quitarme los útiles de mi arte" ${ }_{66}$.

La crisis pudo motivar cierto reacomodo de los talleres artísticos. Algunas de las collaciones más afectadas por el impacto de la peste, que dieron asiento a importantes sectores de la producción artística, como las que arriman a la línea de muralla, como la de Omnium Sanctorum. Precisamente, la calle de la Feria, que se adentra en San Juan de la Palma, a cuyos flancos se situaban muchos obradores de pintura, hubo de sufrir el más duro revés. Y, sin embargo, las collaciones de San Bartolomé y San Nicolás, que tampoco lograron abstraerse de ese mismo envite, mostraron en los primeros años de la década cierta mejoría. A fines de 1650 se coloca el lienzo de Murillo de la Santa Cena en su altar. Y por esas mismas fechas el maestro, recién salido de la dolorosa coyuntura, se estableció en san Nicolás, en cuyo padrón consta en 1651, acompañado de sus dos aprendices, Juan Jacinto Guerra y Juan López Carrasco67. Es evidente que el comercio de Indias, que había marcado este territorio como de su propiedad, tuvo una más rápida y mejor respuesta inmediata tras la calamidad. Aun cuando se habla del empobrecimiento de la ciudad y de las graves mermas en su tráfico con Indias, muchos de los traficantes repartidos por estos barrios colindantes con el de Santa María la Mayor, actuaron con mayor agilidad para salir de la sima.

No podemos dejar de lado una circunstancia relacionada con el consumo privado de arte, que tiene que ver con la pervivencia de los usos tradicionales en los espacios domésticos. Ello motivó la dotación artística de los mismos, manteniéndose la capilla y el estrado como espacios para alojar las obra de arte sacro. Y el patio, más que el vestíbulo, mantendrán su vínculo con el arte profano. Hay documentos que hablan de la existencia en los hogares a principios de los cincuenta, de bodegones de procedencia flamenca, referidos como "nuevos"68. 


\section{II/Los sesenta y el nuevo sistema creativo}

El año sesenta fue muy significativo para la ciudad y su población. Y justo empezó poniendo el broche a una década desconcertante. Lo puso el auto de fe celebrado a mediados de abril de ese año69. Hasta ochenta fueron los reos, en su mayoría, acusados de judaizantes. El lienzo, que es de propiedad privada, primero se encargó a Francisco de Herrera el Mozo, aunque debido al elevado precio en que se tasó, fue traspasado a otro artista, quien probablemente es el que lo hizo en gran parte ${ }^{70}$. De otro lado, hay que significar la celebración en Sevilla del acuerdo de paz de España con Francia. Señalándose la efeméride con "fiestas y común alegría"71.

Hablamos de los sesenta como un nuevo tiempo en que los procesos creativos del cincuenta se concretan en un código formal. Como punto de partida, siguen una serie de indicaciones.

\section{Al cabo de la Corte}

En Madrid se produjo la confluencia de diversas corrientes creativas, en convivencia con una nutrida e influyente élite socioeconómica, que dio protección a algunas de las iniciativas que acabaron en cambios sustanciales en el arte cortesano y en su proyección hacia la periferia. En este sentido hay que considerar la importancia del teatro en la Corte y su incidencia en el desarrollo general de las artes locales. La quadratura que se asocia con la escenografía, propia de un nuevo arte amparado por Calderón y su escuela, tuvo un extraordinario desarrollo por el aporte de dos grandes maestros boloñeses, que había acudido al llamamiento de la Corona. Mitelli y Colonna tuvieron una influencia notoria en la proliferación de este arte. Pero también hay que considerar la alternativa de Herrera el Mozo, con un concepto más cortonesco en sus propuestas creativas. En la década de los cincuenta, en la conjunción de todo esto, surge una nueva pintura escenográfica ${ }^{72}$.

En el caso de Mitelli y Colonna, se tiene noticia de su labor en el Alcázar y en el Palacio del Buen Retiro, a partir de $1658^{73}$.

En el ámbito cortesano se acrisolan las nuevas formas e ideas artísticas que harán suyas los más destacados artistas locales. Retrato como géne- ro de preferencia, perspectiva y geometría en el arte, dibujo como soporte de la creación. Y por encima de todo un concepto que se concreta en este momento, el de la integración de las artes. Santa María la Blanca es el ejemplo.

\section{El periplo cortesano de dos maestros: Murillo} y Valdés

También la Corte ejerció su influencia sobre este lado de la periferia, por lo que respecta al arte, de la mano de un conjunto de ideas que circularon de uno a otro, con la intermediación de varios artistas, principalmente Murillo y Valdés Leal.

Con seguridad hubo de tener influencia en el devenir de escuela el viaje de Murillo. Palomino, que seguramente tenía información de primera mano, alude a que el viajero "vio repetidas vezes las Eminentes Pinturas de Palacio, y del Escorial y otros Sitios Reales, y Casas de Señores; y Copió muchas de Ticiano, Rubens, y Vandic... no descuidandose en el dibujo por las Estatuas, y en las Academias de esta Corte..." 74 . La historiografía reciente ha confirmado dicha estancia en 1658 , confirmándola un documento notarial del 30 de abril75.

Para Murillo fue importante la estancia cortesana, tal como se puede verificar a través de su arte, por el reforzamiento técnico, con atención al dibujo como base de sus creaciones, lo que asimismo le llevó a fundar la Academia de la Lonja. Y también fue muy importante esa experiencia por lo que respecta a la redefinición del retrato como género artístico de especial significación. Hay mucho de leyenda en relación con la estancia cortesana del sevillano, del mismo modo que hay dudas sobre la asunción del modelo de retrato cortesano, que Murillo hará suyo y reproducirá para beneficio de distinguidos miembros de las élites locales. Una circustancia que pude constatar años atrás, que adelantó a los años cuarenta sus primeras experiencias en este terreno, es la que le vincula con el arzobispo Agustín Spínola y los retratos de familia. El pintor no sólo tuvo la oportunidad de conocer de primera mano los retratos familiares, especialmente los del marqués de Leganés y de su esposa, sino que llegó a hacer su propia versión ${ }^{76}$. Es decir que antes del cuarenta y nueve Murillo conocía los retratos del holan- 
dés Van Dyck. De otro lado, habría que considerar la cualificada opinión de Valdovinos, al considerar que el retrato del Marqués de Legarda lo pintó el artista sevillano durante su estancia madrileña ${ }^{77}$.

Y también Valdés Leal tuvo un notorio progreso en su arte en la visita a Madrid. Su viaje está fechado en 1664. Se dice que lo hizo para ver célebres pinturas. "No se sabe, que hiziesse cosa de Pintura, solo si me dixo Claudio Coello, que avia ido a la Academia, y que dibujaba dos, o tres figuras cada noche" 78 .

El viaje a Madrid, donde tanta inspiración pudo tener de la pintura del taller de corte y de lo dispuesto en los grandes palacios madrileños, sino que pudo quedar influido para la etapa creativa que inicia recién retornado a Sevilla, el de la pintura escenográfica. Valdés, en realidad, no es un gran artífice de la perspectiva, como lo sería su hijo, al que se ha debido devolver algunas atribuciones antiguas al padre. En noviembre de 1659 firma con Pedro de Ribas la realización del retablo mayor de la iglesia de San Benito de Calatrava. El primero de una serie donde inicia su despliegue creativo, más allá de policromar la madera. Hoy los muros de la citada iglesia guardan memoria de las andanzas de un lejano seguidor de Valdés, Domingo Martínez, pero es muy probable sobre la vieja creación valdesiana. Otra obra que nos permite caracterizar esta parte de la creación de Valdés es el altar mayor de San Antonio de Padua (1667), el de san Clemente (1680). Y, sin duda, la culminación de un proceso parateatral que permite asimismo hablar de bel composto: el retablo mayor del Hospital de la Caridad, acompañado por Pedro Roldán y Bernardo Simón de Pineda. El alcance de su obra en estos encargos queda de manifiesto en el contrato firmado en 1667 por el que se compromete a hacer "el dorado y estofado del retablo mayor de la iglesia del convento de San Antonio de Padua, con la pintura de las paredes y bóveda del presbiterio"79. Y eso mismo le ocupará en otras obras, siendo de destacar la pieza paradigmática, la del hospital de la Caridad.

\section{Lo parateatral en la cultura barroca}

El teatro en este nuevo tiempo aún tendrá mayor protagonismo en su proyección hacia el resto de las artes. Este desarrollo tendrá que ver con el impulso dado en la Corte a la generación de nuevos espacios escénicos.

La feliz iniciativa del Conde Duque de Olivares de construir el Palacio del Buen Retiro, con su Coliseo, a partir de 1630, está en la base de un cambio sustancial en la relación del teatro con el medio cortesano. Y con ella el desarrollo de la arquitectura y el arte escénico. Las mutaciones que empiezan contribuyendo a la generación del espacio escénico, acaban convirtiéndose en el soporte de todo un arte pictórico decorativo, en el que tomaron parte los artistas que acabarían por desenvolverse en el arte de la quadratura. Al final, se desarrolla desde mediados de siglo un arte que bien podríamos denominar "parateatral", por el hecho de haberse vinculado con el teatro, aun cuando tenga otro uso. Pero será la llamada "comedia grande o de tramoya" la que concierte la acción de todas las artes para general un espectáculo integralso. Y a ello hay que añadir la aportación de Calderón de la Barca, quien en apenas dos décadas, escribió diversas obras que fueron representadas con ayuda del ingeniero Cosme Lotti. La culminación de este proceso personal y creativo se dio con La púrpura de la rosa (1660), que se ha considerado "una representación musical" ${ }^{81}$. El gusto de los principales seguidores de las representaciones de palacio, la familia real, junto con su séquito, que le acompañaba en muchas de ellas, fomentó el despliegue escénico, al punto de que Calderón tuvo conflicto con el arquitecto Lotti, llegándo a exponer su queja en estos términos: "Yo he visto una memoria que Cosme Lotti hizo del teatro y apariencias que ofrece hacer a Su Majestad en la fiesta de la noche de San Juan; y aunque está trazada con mucho ingenio, la traza de ella no es representable por mirar más a la invención de las tramoyas que al gusto de la representación. Y habiendo yo, Señor, de escribir esta comedia, no es posible guardar el orden que en ella se me da" (fig. 9).

En Sevilla tuvo continuidad la cultura teatral cortesana, mediando el siglo. Se ha podido localizar al autor de comedias "por Su Magestad", Fernando Miguel Bermúdez itinerando por los corrales de Sevilla y Jerez ${ }^{82}$.

El teatro fue el crisol donde se fundieron todas estas ideas, pero también motivó un conflicto con 


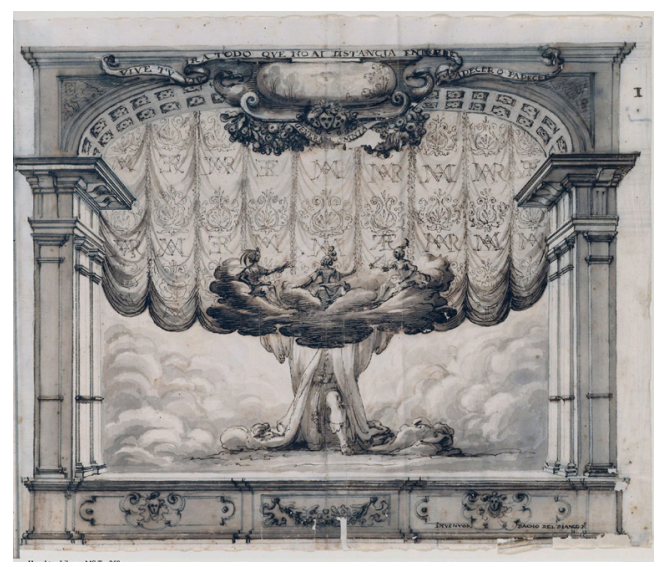

Fig. 9. Baccio del Bianco. Adrómeda y Perseo, de Pedro Calderón de la Barca. Coliseo del Real Palacio del Buen Retiro, 1653 (MS Typ 258, Houghton Library, Harvard University)

la Iglesia, que sólo se resolvió en 1679, con la clausura de los últimos corrales de comediass. Curiosamente, en el desenlace de una campaña de descrédito de este arte, fue trascendental la intervención de Miguel de Mañara. Y lo que es aún más llamativo por volver al punto de retorno de este ensayo, según diría el padre Tirso González: "...que no entraría la peste en Sevilla si se desterrasen las comedias..." ${ }^{84}$. Y con ello también retrocedo para recordar las palabras de Gómez Piñol, al situar en ese suceso el final de una etapa en la historia de esta ciudad.

A todo lo dicho hay que añadir un hecho trascendental en la evolución de las artes del retablo, que junto con la pintura escenográfica, dan la pauta del cambio en los sesenta. El agotamiento del sistema compositivo en uso hasta el momento y su sustitución por uno nuevo, que se hace eco de los desarrollos escénicos.

Se marca hasta 1660 la vigencia del "modelo tetrástilo" en el ámbito de la retablística ${ }^{85}$. Lo que se ha dado en llamar "protobarroco" muestra la primacía de la estructura sobre la decoración. Arquitectura que responde a un sistema expresivo motivado por la Compañía, con un arquitecto que pautó el proceso que llevó al canon, con un sistema tetrástilo de orden colosalob. Una visión del arte arquitectónico de raíces romanas, que se a asociado bien a Palladio y Serlio, pero que tuvo alternativas en la figura de Herrera y el ámbito cortesano, con el Escorial como referente. Lo que, luego de la invención de Alonso Cano y la precedencia de Alonso Matías, concretó el orden tetrástilo, que culminó su trayectoria en 1660. Se ha hablado de revolución barroca con respecto a este orden colosal en clave palladiana ${ }^{87}$.

En el cambio de 1660 hay que consignar un elemento clave, que conecta con el concepto arriba mencionado: la columna salomónica que se presenta como elemento que conciliaba estructura en madera con teatro. Se ha puesto de relieve la importancia del Templo de Salomón ${ }^{88}$. Aunque hay autores que llaman la atención sobre unos inicios más remotos, anteriores a Pineda. Concretamente se ha aludido a la Cartuja de Jerez, en cuyo retablo mayor aparecen, atribuyéndose la idea del soporte salomónico a José de Arce ${ }^{89}$. Sería Felipe de Ribas el responsable último de este cambio que contribuye a la plenitud del barroco en el retablo. Reconfiguró el tetrástilo con el aporte del salomónico ${ }^{90}$.

Academia, formación y dignidad artística, en un nuevo rumbo creativo

Del once de enero de 1660 es el acta fundacional de la Academia. En el primer pasaje se pone en consideración de los lectores, que "Nos los profesores de el arte de la Pintura de cuyos nombres va firmado este instrumento, dezimos que por quanto entre todos los de nuestro Arte esta dispuesto institutir y fundar una academia en que se exerciten nuestros estudios y abiliten a los que se vibieren de vsar ..."

La Academia y la Lonja y la República de las Letras

Kinkead calculó que unos 350 pintores trabajaron en la ciudad en la segunda mitad del XVII. $Y$ aunque se firmaron centenares de contratos de aprendizaje, en una evolución que se ha dibujado como dientes de sierra, con un crecimiento continuado desde el cincuenta hasta el setenta ${ }^{92}$. No llegó a la décima parte los que se involucraron en un trascendental cambio en el refuerzo formativo, propiciado por la Academia de la Lonja, con cuya "institución y fundación" se inaugura la década. Se atribuye a Murillo su creación y por ello se le da su nombre. También se sitúa a Herrera el Mozo en su origen. La más que evidente complicidad 
entre ambos artistas, puesta de manifiesto en la evolución artística del primero a partir del retorno del segundo a Sevilla, tuvo que pesar en la decisión de separar técnica e idea, de trascender el trabajo de obrador para llegar al dibujo y el natural como argumentos. Pero también hubo de influencia la experiencia que tuvo en su visita a la Corte, justo dos años antes. Incluso el propio Ceán Bermúdez adelanta al 1658 la fecha en que Murillo concibió la idea de instituir dicho centro formativo ${ }^{93}$. Todo parece indicar que los asistentes no siempre asumieron a plenitud los principios de la Academia, recogidos en los Estatutos.

El proyecto, que se inspira en el modelo boloñés de los Carracci, pero toma también en consideración las experiencias cortesanas, trata de generar un espacio adecuado para la enseñanza del dibujo sirviéndose de modelos vivos ${ }^{94}$.

La Academia prologó su vida hasta 1674. Adoleció de problemas económicos, a pesar de la protección del conde de Arenales. Corzo resume los problemas del primer año de vida en estos términos: "...no debió obtener el éxito esperado, tanto por la falta de adecuación del espacio disponible como porque buena parte de los que se comprometieron en enero en mantenerla perdieron su interés y dejaron de abonar las cuotas; tampoco parece que la distribución de cargos fuera eficaz..." 95 .

Tal vez no haya correlación entre la creación de la Academia de la Lonja, de pintores y escultores, y la República de las Letras, hermandad de poetas. Sin embargo, no puede negarse que algo había cambiado cuando a principios de la década de los sesenta se produjeron ambas concrecciones. Al menos desde 1662 se ha podido constatar la concurrencia en Academias Literarias, siempre en torno a la celebración del Carnaval. Tan ilustre escritor como Fernando de la Torre Farfán jugó un papel protagonista en la conformación del grupo. Él mismo recordaba en 1665 que no era la primera vez que ejercía como presidente ${ }^{96}$. No fue privativo de Sevilla, ni tan siquiera se ciñó al $X V I I$, puesto que el concepto de "República de las Letras" tuvo una larga maduración que empezó ya en el siglo XVI, derivando hacia el mundo de la filosofía. ${ }^{97}$

Los conciliábulos, celebrados en vísperas de la Cuaresma, tenían un carácter festivo, que con dificultad se conjugaba con los valores religiosos de sus impulsores ${ }^{98}$. He ahí la singuralidad de estas convocatorias, en las que tenían un lugar destacado las justas poéticas ${ }^{99}$. Y con Torre Farfán ejerciendo como máximo exponente de la escuela poética sevillana, al tiempo que lanzó puentes hacia el mundo de las artes. Su conexión con la catedral, las fiestas de la Inmaculada y de san Fernando, para las que redactó algunos textos panegíricos, oportunamente ilustrados con algunas de las mejores creaciones artísticas del momento, le puso en el centro de uno de los más relevantes procesos de cambio de los tiempos barrocos ${ }^{100}$. Conocidas son sus relaciones con Herrera el Mozo, Murillo, Valdés y otros maestros del momento, sin olvidar a Matías de Arteaga que tuvo el acierto de retratarlo para el libro del santo rey ${ }^{101}$.

\section{De las Artes Liberales al Bel Composto}

Nuevamente, la Corte fue el medio en que se alimentó un cambio entre los artistas sevillanos. En 1623 inició el Gremio de Pintores y Doradores madrileños el litigio con la Corona por la onerosa carga de la alcabala. La defensa de la dignidad del arte de la pintura vuelve a la palestra. Un largo itinerario legal que bien podría culminar con el alegato de Gaspar Gutiérrez de los Ríos, autor de la Notizia general para la estimación de las artes ${ }^{102}$. El eco de la pugna con el alcabalero llega a la periferia, donde Sevilla da continuidad en 1652. En abril de ese año el arte de la pintura conoce "la escritura que gano Angelo Nardi" en el pleito con el Consejo de Hacienda por la exención del pago de la alcabala ${ }^{103}$.

Un retorno a la normalidad se produce, desde el arte, con una especie de revuelta legal del colectivo frente a la administración. Así el 20 de diciembre de 1653, los representantes corporativos apoderan a los procuradores de la Real Audiencia para que realicen acciones legales que hoy desconocemos. Y dos años más tarde se repite la acción con sendos poderes otorgados a dos procuradores en los meses de septiembre y octubre. Cuestiones que se nos escapan, pero sin duda relativas al funcionamiento del arte y oficio de la pintura.

Otro signo de este nuevo tiempo es el progreso de las artes hacia su integración. La presencia 
de Herrera el Mozo en Sevilla pudo ser capital para cambiar el orden de las cosas en el seno de los talleres sevillanos y, probablemente, en los gustos en la clientela. Herrera testimonió a través de las pocas obras que hizo en el tiempo que permaneció en la ciudad, antes de retornar a la Corte, su bagaje italiano y probablemente la influencia berniniana, que tanto impacto ocasionó en la ciudad. Baldinucci alabó en Bernini (en su Vida del Caballero Bernini) una cualidad por encima de otras, al ser "el primero que intentó unir la arquitectura con la escultura y la pintura de tal manera que todas hiciesen una hermosa mezcla" o lo que es lo mismo un "bel composto"104.

Al menor de los Herrera luego le encontramos enfrentado al maestro de obras reales José del Olmo, a propósito de la construcción de la basílica del Pilar, en Zaragoza ${ }^{105}$. Habría que leer a Palomino para descubrir la paradójica personalidad artística de Herrera. Aunque categorizado en nuestro medio como pintor, tuvo mayor proyección y reputación en el ámbito cortesano, ejerciendo como arquitecto. El mismo teórico de la pintura nos descubre su talante, en las palabras que supuestamente pronunció: « ¡ El diablo tiene esta pintura en el cuerpo! Porque si he querido ser geómetra, lo he conseguido; si aritmético, también; si arquitecto, lo mismo; y en este diablo de la Pintura, con tanto como me he desvelado en ella, voto a $\mathrm{N}$. que aún no sé dibujar un ojo» ${ }^{106}$. En la Corte fue habitual la intromisión de pintores y escultores en el terreno de los arquitectos, con el triunfo del barroco a mediados de siglo, dada sus cualidades plásticas y ornamentales ${ }^{107}$.

La proyección de este espíritu integrador sobre el arte sevillano se verifica años más tarde, avanzada la década del sesenta y ya dentro del setenta. Y probablemente serían dos obras las que nos permitirían constatarlo: la obra de la iglesia hospitalaria de la Caridad y el montaje de las estructuras y elementos decorativos utilizados para celebrar la fiesta de San Fernando. Aun siendo las más relevantes no fueron las únicas. Sin embargo, la mayoría de las referencias que podemos traer ahora pertenecen a la década siguiente. $Y$ ello queda para otra ocasión. 


\section{NOTAS}

Clarividente fueron Emilio Gómez Piñol y Ma . Isabel Gómez González, concretando su opinión en este pasaje: "En el plano general de la situación del arte sevillano se observa que, paradójicamente, a partir del trágico año de la devastadora peste de 1649, se activaron misteriosas sinergias espirituales y artísticas que determinaron la apertura de una treintena de años decisivos en el arte y la cultura hispalenses que hemos delimitado hasta la fecha crítica de 1679, año en el cual Miguel Mañara, artífice decisivo de una campaña impulsada por algunos medios eclesiásticos, logró del Consejo de Castilla la supresión en Sevilla de las comedias teatrales." Emilio Gómez Piñol y Ma Isabel Gómez González. "El Sagrario de la Santa Iglesia Catedral de Sevilla." Cuadernos de Restauración de Iberdrola VIII (2004): 21.

2 Fray Antonio de Lorea. El siervo de Dios... Fr. Pedro de Tapia, de la Orden de Predicadores, obispo de Segovia, Siguenza, Cordova y arzobispo de Sevilla... historia de su apostólica vida y prodigiosa muerte. Madrid: Imprenta Real, 1676, 285.

3 Completando el pasaje: "fatigaba ya esta a lo fines del año, y no se esperaba el alivio de traerse granos de tierras ultramarinas, porque de ellas se tenia noticia de escasez, que los subiria de precio, y el que tenian los premios de la plata era tan grande, que ponia mayor impedimento a que se alentasen los Mercaderes, que otras veces causaron el alivio con la conducción de gruesas cantidades de trigo y cebada". Ortiz, 75, año 1651

4 Diego Ortiz de Zúñiga, Anales Eclesiásticos y Seculares de la Muy Noble y Muy Leal Ciudad de Sevilla, Metrópoli de Andalucía (Madrid: Imprenta Real, 1796), V, 86. Entre ellos el marqués de Villamanrique y don Fernando Enríquez de Ribera.

5 Archivo Histórico Provincial de Sevilla [AHPS. PN.], lib. 1806, fols. 603608.

\section{AHPS. PN., lib. 1806, fol. 459.}

7 José Maldonado y Dávila le dedica un texto, que se conserva manuscrito: Tractado verdadero del Motin que huuo en la Ciudad de Seuilla este año de 1652. AHPS, Piezas aisladas, lib. 28796. Antonio Domínguez Ortiz, "Documentos sobre el motín de la Feria en 1652," Archivo Hispalense 221-22 (1947): 69-93. José Calvo Poyato, "Recesión y hambre en Sevilla: El Motín de la Feria," La Aventura de la historia 171 (2013): 40-44. Juan Carpio Elías, "Actitudes religiosas durante el levantamiento popular de la Feria: Sevilla, 1652." Hespérides: Anuario de investigaciones 13-14 (2005-2006): 27-42.

8 Ortiz de Zúñiga, Anales, 74.

9 "E Reçeuiodo mucho gusto biendo el buen estado que los alborotos de la plueue desa ciud hauia tomado con tanta Reputacion del seruiçio de Sumag y credito de la justiçia por medio de I anobleça que con tanto valor... dispuisiçion acudieron a ello de que su magd dios... a hecho la estimacion que es justo yo estoy muy..." AHPS. PN. lib. 1807, fol. 991

10 AHPS. PN., lib. 556, fols. 944-6; 23-IV. Probanza de don Juan de Villlacís y Sandoval. En el punto $2^{\circ}$, fol. 954r, refiere el documento: "saue que por el año passado de mil y seios y cinta y dos al tiempo que vbo en esta ciud tumulto y alboroto en el barrio de la feria asistio en ella el dho don Ju de Villaçis por cauo y gobernador de los amotinados procurando con muchas beras Reducirlos y aquietarlos estando todo el tiempo que duro el dho motin en el cuerpo de guarda que hicieron en la casa del sr Marques de la algaua asi de dia como de noche hasta el domingo de la sma trinidad que se les dio el asalto y que es cosa muy constante que trauajo mucho el dho don $\mathrm{Ju}^{\circ}$ de Villacis en ello por andar Armado y preuendio rezelandose no le matasen de cuyo ejercicio y del que tubo prebiniendo los demas cuerpos de guarda para el asalto que se dio y las boces y serenos de aquellas noches se le origino vna destenplanza en el celebro de que se le siguio vna estilaçion al pecho y pulmones con tanto ynpetu y biolencia que le sofocaua y aogaua con el mucho umor que caya en las partes que siruen a la respiraçion y que aunque se le asistio con mucho cuydado a la cara deste achaque abriendole fuentes y dandole muchas sangrias y vsando de los demas remedio sque conbenian $\mathrm{p}^{\mathrm{a}}$ su curacion no obstante le apreto por ynterbalos que avnque se aliuiaua algo, con la continuaçion y perseberançia del corrimto no bastaron todos los dhos remedio pues murio de la dha enfermd $y$ que esto que tiene dho lo saue por el mucho conocimto que tubo con el dho don Ju ${ }^{\circ}$ de Villacis y pñor hauerle curado de la dha enfermd hasta que murio dellla juntamte con el doctor $\mathrm{Al}^{\circ}$ granados..."

11 "...Fueron presos de los más culpados, y arcabuceados luego... enviando otros á la Cárcel Real, de que luego sacaron a ajusticiar con igual suplicio... [a] los más insolentes en el motín". Ortiz de Zúñiga, Anales, 99.

12 Ibid., 107.

13 José Jaime García Bernal, "El ritual funerario de los Arzobispos de Sevilla según los cuadernos manuscritos de los maestros de ceremonias de la catedral hispalense (siglos XVII-XVIII)." eSpania [En ligne], 17, 2014, mis en ligne le 26 février 2014, consulté le 09 juillet 2020. URL : http://journals.openedition. org/e-spania/23398; DOI : https://doi. org/10.4000/e-spania.23398

14 A pesar de los años, sigue siendo la lectura obligada en relación a este tema: Juan Ignacio Carmona García. La peste en Sevilla. Sevilla: Ayuntamiento, 2004. Y por lo que respecta al motín quiero recordar el valioso trabajo de Antonio Domínguez Ortiz: "Documentos sobre el motín de la Feria de 1652." Archivo Hispalense 21-22 (1947): 69-93. No son los únicos trabajos, pero sí son los más oportunos para fundamentar este estudio.

15 Me ocupé de ello en el artículo "En los cimientos de la Iglesia sevillana. Fernando III, rey y santo." Bol. del Museo e Instituto Camón Aznar 75-76 (1999): 203-250. También fue objeto de estudio de Amanda Wunder: "Murillo and the Canonisation Case of San Fernando, 1649-52." The Burlington Magazine 143:1184 (2001): 670-675; "Un pintor, un cadáver, y un retratola imaginería de Fernando III en la Sevilla barroca." Estudios de historia iberoamericana. XXXIII Reunión de la SSPHS, M Soledad Gómez Navarro y José M. de Bernardo Ares, coords. (Córdoba: Universidad, 2003): 128-132 
16 Pablo Hereza, Corpus Murillo. Biografía y documentos (Sevilla: ICAS, 2017), 250.

17 Testificó en la declaración de la última voluntad de José Suero, fallecido con la peste: "...Saue que el susodho estando en el articulo de la muerte por no ayer escribano ante quiepoder lo otorgar hiço y otorgo la dha memeoria que le a ssido leida". AHPS. PN., Lib. 540, fol. 416, 20-VIII-1649.

18 Tal como queda expuesto en el testamento de 26 de agosto. AHPS. PN. Lib. 1801, fols. 568-570.

19 Término acuñado por Fermín de los Reyes Gómez, en "La estructura formal del libro antiguo español." Paratesto 7 (2010): 21. También Carlos M. Collantes Sánchez. "La búsqueda del mecenazgo a través de la poesía sevillana impresa (1649-1682)." Janus 9 (2020): 96.

20 Alonso Hortiz de Viedma, maestro albañil de la collación de Omnium Sanctorum, da carta de pago a Fernando Moreno, mayordomo de la fábrica de la iglesia de San Juan de la Palma, por valor de 1771 reales, el monto total de la solería que hizo para el citado templo, con el levantamiento de la del coro. Más 48 reales percibidos por los peones. AHPS, PN. Lib. 541, fol. 520; 30-XI-1649.

21 AHPS. PN. Lib. 548, fol. 433. El nuevo contrato se firmó el 30 de junio de 1650 .

22 Fue Jesús Aguado de los Reyes quien primero hizo balance del registro documental: "La peste de 1649: Las co\|laciones de Santa Cruz y San Roque." Archivo Hispalense 72 (1989): 45-56.

23 El 25 de septiembre de 1651. Fernando Quiles. "Sevilla, barroca y renaciente (1649-1675)." In: Ma . de los Ángeles Fernández Valle, Carme López Calderón e Inmaculada Rodríguez Moya. Espacios y muros del barroco iberoamericano (Sevilla-Santiago: Enredars-Andavira, 2019): 13-37.

24 Ibidem.

25 Hay que hacer un expurgo de la historiografía, puesto que más allá de Hamilton, que usó la documentación oficial de la Casa de Contratación, para la que se ocultó no poco contrabando, habría que considerar las referencias de registros holandeses que apuntan en otra dirección. Ramón María Serrera Contreras. "¿Esplendor o declive?: Sevilla en 1650 y la plata americana." In Ma Salud Elvás y Sandra Olivero, coords. Redescubriendo el Nuevo Mundo: Estudios americanistas en homenaje a Carmen Gómez (Sevilla: Universidad, 2012): 17-29.

26 Juan A. Sánchez Belén. "El comercio holandés de las especias en España en la segunda mitad del siglo XVII." HISPANIA. Revista Española de Historia LXX/236 (2010): 649.

27 Michel Morineau. "Un aluvión de oro y plata: Los caudales de Indias," in España y América: Un océano de negocios, 1503-2003, coord. Guiomar de Carlos Boutet (Sevilla: Sociedad Estatal Quinto Centenario, 2003): 220. Más en: Stanley J. Stein y Barbara H. Stein. Plata, comercio y guerra: España y Emérica en la formación de la Edad moderna (Barcelona: Crítica, 2002).

28 María Josefa Arnall Juan. "El 'Itinerario a Indias' (1673-1679) del P. Fr. Isidoro de la Asunción, C.D. (Manuscrito 514 de la Biblioteca Provincial y Universitaria de Barcelona)." Boletín Americanista 28 (1978): 222 y ss.

29 Más en Ramón Ma Serrera Contreras. "Lope de Vega y 'El Arenal de Sevilla'. "Boletín de la Real Academia Sevillana de Buenas Letras: Minervae Baeticae 35 (2007): 163.

30 "Yo, don Miguel Mañara, ceniza y polvo, pecador desdichado, pues lo más de mis logrados días ofendí a la Majestad altísima de Dios, mi Padre, cuya criatura y esclavo vil me confieso. Servía a Babilonia y al demonio, su príncipe, con mil abominaciones, soberbias, adulterios, juramentos, escándalos y latrocinios; cuyos pecados y maldades no tienen número y sólo la gran sabiduría de Dios puede numerarlos, y su infinita paciencia sufrirlos, y su infinita misericordia perdonarlos". Así se expresa Miguel de Mañara en su testamento. Tomo el pasaje de Francisco Martín Hernández. Miguel de Mañana (Sevilla: Universidad, 1981): 49.

31 Se ha podido constatar documentalmente la ceremonia de imposición del hábito de caballero de la Orden de Calatrava de don Diego Fernández de Córdoba, siendo padrino don Juan de Villasís y testigos, aparte Miguel de Mañara, otros próceres locales. La ceremonia se celebró el 1 de agosto de 1650, en el convento de Sta. María de las Dueñas, od. San Benito y san Bernardo y, en suma, supuso que "los señores don luis federigui y don migl mañara le pusieron y calçaron dos espuelas doradas y el dho don Pedro nuñez de $v^{a}$ vicencio puso al dho Don Diego fernandez de Cordoua una espada dorada y asi puesta y ceñida se la boluio a sacar de la bayna y teniendola desnuda en la mano le dijo y pregunto tres beces Don Diego fernandez de Cordoua quereis ser cauallero y otras tantas beces el susodho dijo y respondio si quiero ser cauallero y otras tres veces el dho señor don pedro nuñez de vabicencio dijo Dios todo poderoso os haga buen cauallero y el señor san Venito y san Berndo sean buestro abogados y le toco con la dha espada en la caueza y en los ombros y se la bolvuio a entrar en la Bayna el dho don Pedro nuñez de villavicencio a todo lo qual los dhos ses caualero estubieron bestidos con sus mantos blancos con ynsinias de la dha horden de Calatraua y el dho señor Don Diego fernandez de Cordoua pidio a mi el dh son $\mathrm{pu}^{\circ} \mathrm{le}$ de por testim los sudoho para que en todo tiempo conste... //vto. $Y$ el dho señor Don frey martin pizarro dijo que las obedecia y obedeçio con el respeto debido y que esta presto de las cumplir (provisiones) y de dar el auito e ynsine de la dha horden de calatraua a el dho don diego fernandez de cordoua como su magd lo manda... y en presencia de Is dhos señores caualleros y de mi el dho esno y testigos el dho sr don fray martin piçarro hico sentar en el suelo a I dho don diego fernandez de cordoua y se le leyeron por vn libro de las constituciones de la dha horden de Calatraua ciertas pregtas y puesto de rodillas le bistio y puso vn escapulario y manto blanco con la dha ynsinia de la dha horden..." AHPS. PN. Lib. 544, fols. 395-396.

32 Oliver Piveteau. Don Miguel Mañara. Frente al mito de Don Juan. Sevilla: Fundación Cajasol, 2007.

33 Fray Antonio de Lorea. El siervo de Dios... 234.

34 El socorro a la obra se relata en: Ibidem, 234-235.

35 Ibidem, 243. 
36 José Antonio Maravall. La cultura del Barroco (Barcelona: Ariel, reimpr. 1985): 327; Fernández Basurte, Federico. "Epidemias y manifestaciones religiosas en la Málaga del siglo XVII. La Virgen de la Victoria." Baética: Estudios de arte, geografía e historia 16 (1994): 307.

37 Las fuentes refieren una "fiesta de la batalla naval". Hereza, Corpus Murillo 298-299. La atribución a Murillo en: Jorge Bernales Ballesteros. "Presencia de Murillo en las fiestas barrocas de Sevilla." Murillo y su época (Sevilla: Ministerio de Cultura, 1982): 1-43.

38 Miguel Cid registra la fundación de una fiesta en beneficio de la cofradía del Stmo. Sacramento de San Martín. Documento fechado el 13 de enero de 1651. AHPS. PN., Lib. 546, fols. 195-199.

39 La fiesta al Santísimo de Omnium Sanctorum, con un juro de 15.049 reales, en: AHPS. PN., Lib. 546, fols. 247-253.

40 Hereza, Corpus Murillo, doc. 54, pág. 271.

41 Diego Angulo. "Murillo en Marchena. El retablo de San Agustín de Sevilla. Las copias de los cuadros de La Caridad." Boletín de la Real Academia de la Historia 149 (1961): 25-36.

42 Jesús Aguado de los Reyes, La peste.

43 Francisco de Castro, autor de comedias, acuerda con don Joseph Rafael, que tiene a su cargo el corral del Coliseo, cuarenta representaciones, desde la fecha y por 270 reales diarios. Referido queda que no se han de efectuar las representaciones en el corral de la Montería. AHPS. PN., Lib. 544, fol. $802 ; 1650$.

44 Acuerdo con los carreteros de mulas de la Puente de don Gonzalo, para que desde Córdoba lleven "a Luis lopez autor de comedias, que de prte rezide en la dha çiudad de cordoba, para la villa de md con su gente y toda su ropa con siete carros de a dos mulas cada uno". AHPS. PN., Lib. 1808, fols. 667-668; 1652.

45 La Misericordia tenía corral de comedias propio, donde se celebrarían representaciones veinte días después del Corpus. AHPS. PN., Lib. 550, fols. 660-1; 1652.
46 Y el valor didáctico de los autos sacramentales ha sido puesto de relieve en numerosas ocasiones. Valga a modo de ejemplo un caso tan significativo como el de la producción franciscana en la Nueva España durante el XVI, estudiado por Jesús Lara Coronado en "La educación moral en los autos sacramentales del siglo XVI en Nueva España." Perfiles educativos 34 (2012): 79-97. Recuperado en 19 de julio de 2020, de http://www.scielo.org.mx/scielo. php?script=sci_arttext $\&$ pid $=$ S0185$26982012000200006 \&$ lng=es\&tlng= es.

47 El día de fiesta por la tarde (Madrid: Impr. María de Quiñones, 1660): 47.

48 José Antonio Hernández Guerrero. "Defensa de la retórica barroca". Edad de oro 23 (2004): 41-51.

49 Juan Bautista Escardó. Rhêtorica Christiana (Mallorca: Herederos de Gabriel Guasp, 1647). Más en Luis Robledo Estaire. "El sermón como representación: Teatralidad y musicalidad en la oratoria sagrada española de la Contrarreforma." Revista de musicología 26/1 (2003): 127-186. Por lo que respecta al papel del predicador: Jaume Garau Armengual. "La predicación de Juan Bautista Escardó (Palma de Mallorca [1581]-1652) a través de uno de sus sermones." In Actas IV Congreso AISO. $M^{a}$. Cruz García de Enterría y Alicia Cordón Mesa, eds lits. (Alcalá: Universidad, 1998): 625-630. También: Juan Luis González García. "Técnicas jesuíticas de predicación misional, del Viejo al Nuevo Mundo (c. 1550-1650)". )." In Barroco vivo, Barroco continuo, Fernando Quiles y $\mathrm{M}^{\mathrm{a}}$ del Pilar López, eds. lits. (Bogotá/ Sevilla: UNC/Enredars, 2019): 368-385.

50 Perla Chincilla Pawling. "Sobre la retórica sacra en la era barroca." Estudios de Historia Novohispana 29 (2003): 109.

51 Miguel Ángel Núñez Beltrán hizo recuento de 239 sermones, de los que sólo 78 son de la segunda mitad de siglo, una reducción que achaca al descenso de la producción libraria y la crisis de la predicación. La oratoria sagrada de la época del barroco. doctrina, cultura y actitud ante la vida desde los sermones sevillanos del siglo XVII (Sevilla: FOCUS, 2000): 60.
52 María Teresa Dabrio González. "El retablo en la escuela sevillana del Seiscientos." Imafronte 3-5 (19871989): 198.

53 Teodoro Falcón Márquez. “El arquitecto de retablos y escultor Martín Moreno y los primeros retablos con columnas salomónicas en Sevilla." Boletín de arte 34 (2013): 72

54 La columna "tuerta", como Vignola la llama en su Regla de los cinco órdenes de Architectura, que en España fue conocida por la edición de Patricio Caxés, de 1593. Véase: Fernando Marías. "Alonso Cano y la columna salomónica." Figuras e imágenes del BArroco. Estudios sobre el barroco español y sobre las obras de Alonso Cano (Madrid: Fundación Argentaria, 1999): 291-321. Y también: Falcón, "El arquitecto", 72.

55 Ricardo González. " "Los retablos barrocos y la Retórica cristiana." Actas III CIBI: Territorio, Arte, Espacio y Sociedad (Sevilla: UPO, 2001): 578.

56 Juan José Martín González. "Avance de una tipología del retablo barroco." Imafronte 3-5 (1987-1989): 127.

57 AHPS. PN., Lib. 553, fol. 532; 11-III-1653. Ma . Teresa Dabrio González. Felipe de Ribas (Sevilla: Diputación Provincial, 1985): 82, 348-9 y Kinkead, Pintores, 180.

58 Teodoro Falcón Márquez. "La Cárcel Real de Sevilla." Laboratorio de Arte 9 (1996): 164.

59 Gómez Piñol y Gómez González, "El Sagrario", 13-145.

60 José Sánchez-Arjona. Noticias referentes a los anales del teatro en Sevilla desde Lope de Rueda hasta fines del siglo XVII (Sevilla: Imprenta de E. Rasco, 1898): 386.

61 Fernando Quiles. “...Eppur si muove. La pintura sevillana después de la peste negra (1650-1655)." Anuario del Dpto. de Historia y Teoría del Arte 21 (2009): 195.

62 El pintor Alonso de Zamora está avecindado en la collación de San Juan de la Palma. AHPS. PN., Lib. 546, fol. 511, 3-III-1651.

63 AHPS. PN., Lib. 549, Fol. 308; 4-XII-1651. 
64 Fernando Quiles. "Entre mediano y pequeño, entre la capilla y el hogar. Consumo privado de escultura menuda en la Sevilla barroca". En prensa.

65 Quiles, "Eppur", 196

66 Ibidem.

67 Hereza, Corpus, 249.

68 En la dote de doña Ines Blandón, doncella e hija de Fernando Pinto Blandón y doña Guiomar de Quadros, ambos difuntos, que contrae matrimonio con don Joseph de Alderete, hijo Domingo de Alderete y Monroi y doña Catalina Bazquez, también fallecidos, figura este pasaje: 5r. "Yten seis frutteros de flandes nueueos a tres ducados". También seis cuadros de devoción que son descritos como "usados". AHPS. PN., Lib. 545, fol. 425r; 27-X-1650.

69 Rafael Japón. "El Auto de Fe de 1660El gran teatro de la muerte en Sevilla." Revista de la Inquisición (Intolerancia y derechos humanos) 19 (2015): 119-137.

70 Consuelo Maqueda Abreu. El auto de fe (Madrid: Istmo, 1995): 152.

71 Ortiz de Zúñiga, Anales, lib. XVII, 128.

72 A su llegada a Madrid, en 1660, "donde su fama creció como diseñador de pinturas murales al introducir formas compositivas cortonescas frente a las quadraturas boloñesa que venían realizándose." Antonio García Baeza. "Francisco de Herrera el Mozo, un artista al servicio de Carlos II." Anuario del Dpto. de Historia y Teoría del Arte 28 (2016): 142.

73 García Cueto, David. La estancia española de los pintores boloñeses Agostino Mitelli y Angelo Michele Colonna, 1658-1662. Granada: Universidad, 2005.

74 García Cueto, La estancia, 420.

75 Iniciamente dado a conocer por Angulo: "La Piedad de Murillo del Museo de Sevilla. El viaje del pintor a Madrid." Archivo Español de Arte 32/126 (1959): 146-149. Transcrito en: Hereza, Corpus, 341-343, doc. 99.

76 Quiles, "El cardenal".

77 José Manuel Cruz Valdovinos. "Notas sobre la clientela de Murillo." In Murillo ante su IV Centenario. Perspectivas historiográficas y culturales. Actas del Congreso Internacional, Benito Na- varrete Prieto, dir. (Sevilla: Universidad/ ICAS, 2019) 196-197.

78 Antonio Palomino Velasco. El Parnaso Español Pintoresco y Laureado (Madrid: Lucas Antonio de Bedmar, 1724), 438, t. III. José Fernández López. Programas iconográficos de la pintura barroca sevillana del siglo XVII (Sevilla: Universidad, 2002): 223.

79 Duncan T. Kinkead. Pintores y doradores en Sevilla: 1650-1699. Documentos (Bloomington: AuthorHouse, 2007), 579.

80 Díez Borque, José María. «Palacio del Buen Retiro: Teatro, fiesta y otros espectáculos para el Rey.» In La década de oro en la comedia española, 16301640: Actas de las XIX Jornadas de Teatro Clásico, Felipe B. Pedraza Jiménez, coord. (Ciudad Real: Universidad de Castilla-La Mancha, 1997): 170.

81 Valga la síntesis de Erwin Heverbeck. "El teatro cortesano del siglo XVII". Documentos Lingüísticos y Literarios, 10 (1984), 31-39.

82 454-5. En 1654, F. Miguel Bermúdez, autor de comedias por Su Magestad, se compromete a actuar con su compañía en el corral de Jerez de la Frontera, de acuerdo a las condiciones fijadas con los administradores del mismo, Cristóbal Pacheco y Pedro Jorge Adalid. AHPS. PN., Lib. 556, fols. 4545. Algunos días más tarde se concreta acuerdo también con el Coliseo sevillano. Idem, fols. 470-1.

83 Interesante texto, al respecto, el de Piedad Bolaños Donoso. "De cómo hostigó la Iglesia el teatro de Sevilla y su Arzobispo (1679-1731)." In Estudios sobre el teatro del Siglo de Oro, Dolores González Martínez, coord. (Lleida: Universitat, 2002): 65-88.

84 Según Antonio Estúriz Laso de Estrada, Defensa de la poesía Cómica, Trágica y otras diversiones (Sevilla: Manuel Nicolás Vázquez, 1769): 41; tomado de Piedad Bolaños Donoso. "De cómo hostigó...", 65.

85 Andrés Luque marca nítidamente las fechas de la trayectoria de este modelo: 1600-1660. Andrés Luque Teruel, "Origen del retablo barroco en Sevilla: El modelo tetrástilo, 16001660." Espacio y Tiempo. Revista de Ciencias Humanas, 22 (2008): 143-189.

86 Luque, "Origen", 144.
87 Luque, considerando la opinión de Harold E. Wethey. Alonso Cano. Pintor, escultor y arquitecto (Madrid: Alianza, 1983) 38.

88 Luque, "Origen", 172.

89 Luque, "Origen", 172. Sobre la Cartuja valgan los comentarios de César Pemán en "La reconstrucción del retablo de la Cartuja de Jerez de la Frontera. Archivo Español de Arte 23/91 (1950): 203-228.

90 Luque, "Origen", 173.

91 Ramón Corzo. La Academia de Arte de la Pintura se Sevilla, 16601674. Sevilla: Instituto de Academias de Andalucía, 2009: 21. Al respecto podrían considerarse algunas lecturas complementarias, como las más actualizadas de Antonio García Baeza, titulada Entre el obrador y la academia: la enseñanza de las artes en Sevilla durante la segunda mitad del Seiscientos (Sevilla: ICAS, 2014) y la de Rafael de Besa Gutiérrez, sobre "La Academia del Arte de la Pintura de Sevilla." In Coleccionismo, mecenazgo y mercado artístico. Su proyección en Europa y América, Antonio Holguera Cabrera, Ester Prieto Ustio y María Uriondo Lozano, coords. (Sevilla: Universidad, 2018): 713-726.

92 Quiles, Eppur, 197.

93 Juan A. Ceán Bermúdez. Carta de D. Juan Agustin Cean Bermudez a un amigo suyo, sobre el estilo y gusto en la pintura de la escuela sevillana (Cádiz: Casa de la Misericordia, 1806): 64.

94 Corzo, La Academia, 15.

95 Corzo, La Academia, 35.

96 Cipriano López Lorenzo. "Academias literarias en Sevilla: 1665, 1666, y 1667." Etiopicas. Revista de letras renacentistas 10 (2014): 153-154.

97 Interesante síntesis es la de José Pardo Tomás. El libro científico en la República de las Letras. Madrid: CSIC, 2010.

98 López, "Academias literarias, 161.

99 Ibidem.

100 Montero, Juan. "Una polémica literaria en la Sevilla de la segunda mitad del XVII. El Templo panegírico (1663) de Fernando de la Torre Farfán atacado y defendido." Bulletin Hispanique 115-1 (2013): 27-48.

101 Montero, "Una polémica", 28. 
102 Díez-Monsalve Giménez, Juan Antonio y Susana Fernández de Miguel. "Documentos inéditos sobre el famoso pleito de los pintores: El largo camino recorrido por los artistas del siglo XVII para el reconocimiento de su arte como liberal." Archivo Español de Arte, 330 (2010) 154. Cervelló Grande, José Ma. Gaspar Gutiérrez de los Ríos y su "Noticia general para la estimación de las artes. Madrid: Fundación de Apoyo a la Historia del Arte Hispánico, 2006
103 Kinkead, Pintores, 66.

Olmo, Donoso y Ardemans." Espacio,

104 Rodríguez G. de Ceballos, Alfonso. "El 'bel composto' berniniano a la española." In monográfico dedicado a Cultura, poder y mecenazgo, Alfredo M. Vigo Trasancos, ed. Semata. Ciencias sociais e humanidades 10 (1998), 267.

105 Blasco Esquivias, Beatriz. "Sobre el debate entre arquitectos profesionales y arquitectos artistas en el barroco madrileño.Las posturas de Herrera,
Tiempo y Forma. Serie VII. Historia del Arte 4 (1991), 159-194.

106 Un pasaje de la obra de Antonio Palomino (Vidas. Madrid: Alianza, 1986, 284), que subraya Blasco "Sobre el debate", 159.

107 Blasco, "Sobre el debate", 168. 


\section{REFERENCIAS}

Aguado de los Reyes, Jesús. "La peste de 1649: Las collaciones de Santa Cruz y San Roque." Archivo Hispalense 72 (1989): 45-56.

Angulo, Diego. "La Piedad de Murillo del Museo de Sevilla. El viaje del pintor a Madrid." Archivo Español de Arte 32/126 (1959): 146-149.

Angulo, Diego. "Murillo en Marchena. El retablo de San Agustín de Sevilla. Las copias de los cuadros de La Caridad." Boletín de la Real Academia de la Historia 149 (1961): 25-36.

Arnall Juan, Ma. Josefa. "El 'Itinerario a Indias' (1673-1679) del P. Fr. Isidoro de la Asunción, C.D. (Manuscrito 514 de la Biblioteca Provincial y Universitaria de Barcelona)." Boletín Americanista 28 (1978): 222 y ss.

Bernales Ballesteros, Jorge. "Presencia de Murillo en las fiestas barrocas de Sevilla." In Murillo y su época, 1-43. Sevilla: Ministerio de Cultura, 1982.

Blasco Esquivias, Beatriz. "Sobre el debate entre arquitectos profesionales y arquitectos artistas en el barroco madrileño.Las posturas de $\mathrm{He}$ rrera, Olmo, Donoso y Ardemans." Espacio, Tiempo y Forma. Serie VII. Historia del Arte 4 (1991), 159-194. https://doi.org/10.5944/ etfvii.4.1991.2172

Bolaños Donoso, Pieda. “De cómo hostigó la Iglesia el teatro de Sevilla y su Arzobispo (16791731)." In Estudios sobre el teatro del Siglo de Oro, Dolores González Martínez, coord., 65-88. Lleida: Universitat, 2002.

Calvo Poyato, José. "Recesión y hambre en Sevilla: El Motín de la Feria." La Aventura de la historia 171 (2013): 40-44.

Carmona García, Juan Ignacio. La peste en SeviIla. Sevilla: Ayuntamiento, 2004.

Carpio Elías, Juan. "Actitudes religiosas durante el levantamiento popular de la Feria: Sevilla, 1652." Hespérides: Anuario de investigaciones 13-14 (2005-2006): 27-42.

Ceán Bermúdez, Juan A. Carta de D. Juan Agustin Cean Bermudez a un amigo suyo, sobre el estilo y gusto en la pintura de la escuela sevillana. Cádiz: Casa de la Misericordia, 1806.
Cervelló Grande, José Ma. Gaspar Gutiérrez de los Ríos y su "Noticia general para la estimación de las artes. Madrid: Fundación de Apoyo a la Historia del Arte Hispánico. 2006.

Chinchilla Pawling, Perla. "Sobre la retórica sacra en la era barroca." Estudios de Historia Novohispana 29 (2003): 97-122. https://doi. org/10.22201/iih.24486922e.2003.029.3600

Collantes Sánchez, Carlos M. "La búsqueda del mecenazgo a través de la poesía sevillana impresa (1649-1682)." Janus 9 (2020): 92-118.

Corzo, Ramón. La Academia de Arte de la Pintura se Sevilla, 1660-1674. Sevilla: Instituto de Academias de Andalucía, 2009.

Cruz Valdovinos, José Manuel. "Notas sobre la clientela de Murillo." In Murillo ante su IV Centenario. Perspectivas historiográficas y culturales. Actas del Congreso Internacional, Benito Navarrete Prieto, dir., 196-197. Sevilla: Universidad/ICAS, 2019.

Dabrio González, Ma . Teresa. Felipe de Ribas. Sevilla: Diputación Provincial, 1985.

Dabrio González, Ma. Teresa. "El retablo en la escuela sevillana del Seiscientos." Imafronte 3-5 (1987-1989): 187-206.

De Besa Gutiérrez, sobre "La Academia del Arte de la Pintura de Sevilla." In Coleccionismo, mecenazgo y mercado artístico. Su proyección en Europa y América, Antonio Holguera Cabrera, Ester Prieto Ustio y María Uriondo Lozano, coords., 713-726. Sevilla: Universidad, 2018.

De los Reyes Gómez, Fermín. "La estructura formal del libro antiguo español." Paratesto 7 (2010): 9-59.

Díez Borque, José María. "Palacio del Buen Retiro: Teatro, fiesta y otros espectáculos para el Rey." In La década de oro en la comedia española, 1630-1640: Actas de las XIX Jornadas de Teatro Clásico, Felipe B. Pedraza Jiménez, coord., 167-189. Ciudad Real: Universidad de Castilla-La Mancha, 1997.

Díez-Monsalve Giménez, Juan Antonio y Susana Fernández de Miguel. "Documentos inéditos sobre el famoso pleito de los pintores: El largo camino recorrido por los artistas del 
siglo XVII para el reconocimiento de su arte como liberal." Archivo Español de Arte, 330 (2010), 149-158. https://doi.org/10.3989/ aearte.2010.v83.i330.422

Domínguez Ortiz, Antonio. “Documentos sobre el motín de la Feria en 1652." Archivo Hispalense 221-22 (1947): 69-93.

Escardó, Juan Bautista. Rhêtorica Christiana. MaIlorca: Herederos de Gabriel Guasp, 1647.

Estúriz Laso de Estrada, Antonio. Defensa de la poesía Cómica, Trágica y otras diversiones. Sevilla, Manuel Nicolás Vázquez, 1769.

Falcón Márquez, Teodoro. "La Cárcel Real de Sevilla." Laboratorio de Arte 9 (1996): 157-170.

Falcón Márquez, Teodoro. "El arquitecto de retablos y escultor Martín Moreno y los primeros retablos con columnas salomónicas en Sevilla." Boletín de arte 34 (2013): 69-87.

Fernández Basurte, Federico. “Epidemias y manifestaciones religiosas en la Málaga del siglo XVII. La Virgen de la Victoria." Baética: Estudios de arte, geografía e historia 16 (1994): 305-320.

Fernández López, José. Programas iconográficos de la pintura barroca sevillana del siglo XVII. Sevilla: Universidad, 2002.

Garau Armengual, Jaume. "La predicación de Juan Bautista Escardó (Palma de Mallorca [1581]-1652) a través de uno de sus sermones." In Actas IV Congreso AISO, Ma. Cruz García de Enterría y Alicia Cordón Mesa, eds lits., 625-630. Alcalá: Universidad, 1998.

García Baeza, Antonio. Entre el obrador y la academia: la enseñanza de las artes en Sevilla durante la segunda mitad del Seiscientos. Sevilla: ICAS, 2014.

García Baeza, Antonio. "Francisco de Herrera el Mozo, un artista al servicio de Carlos II." Anuario del Dpto. de Historia y Teoría del Arte 28 (2016): 141-152.

García Bernal, José J. "El ritual funerario de los Arzobispos de Sevilla según los cuadernos manuscritos de los maestros de ceremonias de la catedral hispalense (siglos XVII-XVIII)." e-Spania [En ligne], 17, 2014, mis en ligne le
26 février 2014, consulté le 09 juillet 2020. https://doi.org/10.4000/e-spania.23398

García Cueto, David. La estancia española de los pintores boloñeses Agostino Mitelli y Angelo Michele Colonna, 1658-1662. Granada: Universidad, 2005.

Gómez Piñol, Emilio, y Ma Isabel Gómez González. "El Sagrario de la Santa Iglesia Catedral de Sevilla." Cuadernos de Restauración de Iberdrola VIII (2004): 9-62.

González, Ricardo. "Los retablos barrocos y la Retórica cristiana." In Actas III CIBI: Territorio, Arte, Espacio y Sociedad, 45. Sevilla: UPO, 2001.

González García, Juan Luis. "Técnicas jesuíticas de predicación misional, del Viejo al Nuevo Mundo (c. 1550-1650)." In Barroco vivo, Barroco continuo, Fernando Quiles y $\mathrm{M}^{a}$ del Pilar López, eds. lits., 368-385. Bogotá/Sevilla: UNC/Enredars, 2019.

Heverbeck, Erwin. "El teatro cortesano del siglo XVII." Documentos Lingüísticos y Literarios, 10 (1984): 31-39.

Japón, Rafael. "El Auto de Fe de 1660El gran teatro de la muerte en Sevilla." Revista de la Inquisición (Intolerancia y derechos humanos) 19 (2015): 119-137.

Kinkead, Ducan T. Pintores y doradores en Sevilla: 1650-1699. Documentos. Bloomington: AuthorHouse, 2007.

Hereza, Pablo. Corpus Murillo. Biografía y documentos. Sevilla: ICAS, 2017.

Hernández Guerrero, José Antonio. “Defensa de la retórica barroca". Edad de oro 23 (2004): 41-51.

Lara Coronado, Jesús. "La educación moral en los autos sacramentales del siglo XVI en Nueva España." Perfiles educativos 34 (2012): 79-97. Recuperado en 19 de julio de 2020, de http:// www.scielo.org.mx/scielo.php?script=sci_ arttext\&pid=S0185-26982012000200006\&ln $\mathrm{g}=\mathrm{es} \& \operatorname{lng}=\mathrm{es}$.

López Lorenzo, Cipriano. "Academias literarias en Sevilla: 1665, 1666, y 1667." Etiopicas. Revista de letras renacentistas 10 (2014), 151-188. 
Lorea, Fray Antonio de. El siervo de Dios... Fr. Pedro de Tapia, de la Orden de Predicadores, obispo de Segovia, Siguenza, Cordova y arzobispo de Sevilla... historia de su apostólica vida y prodigiosa muerte. Madrid: Imprenta Real, 1676.

Luque Teruel, Andrés. "Origen del retablo barroco en Sevilla: El modelo tetrástilo, 16001660." Espacio y Tiempo. Revista de Ciencias Humanas, 22 (2008): 143-189.

Maldonado y Dávila, José. Tractado verdadero del Motin que huuo en la Ciudad de Seuilla este año de 1652. Ms: AHPS. Piezas aisladas, 28796.

Maqueda Abreu, Consuelo. Auto de Fe. Madrid: Istmo, 1995.

Maravall, José Antonio. La cultura del Barroco. Barcelona: Ariel, 1985.

Marías, Fernando. "Alonso Cano y la columna salomónica." Figuras e imágenes del BArroco. Estudios sobre el barroco español y sobre las obras de Alonso Cano. Madrid: Fundación Argentaria, 1999.

Martín González, Juan José. "Avance de una tipología del retablo barroco." Imafronte 3-5 (1987-1989): 111-156.

Martín Hernández, Francisco. Miguel de Mañana. Sevilla: Universidad, 1981.

Montero, Juan. "Una polémica literaria en la Sevilla de la segunda mitad del XVII. El Templo panegírico (1663) de Fernando de la Torre Farfán atacado y defendido." Bulletin Hispanique 115-1 (2013): 27-48. https://doi.org/10.4000/ bulletinhispanique.2328

Morineau, Michel. "Un aluvión de oro y plata: Los caudales de Indias." In España y América: Un océano de negocios, 1503-2003, coord. Guiomar de Carlos Boutet, 209-222. Sevilla: Sociedad Estatal Quinto Centenario, 2003.

Núñez Beltrán, Miguel Ángel. La oratoria sagrada de la época del barroco. doctrina, cultura y actitud ante la vida desde los sermones sevillanos del siglo XVII. Sevilla: FOCUS, 2000.

Ortiz de Zúñiga, Diego. Anales Eclesiásticos y Seculares de la Muy Noble y Muy Leal Ciudad de Sevilla, Metrópoli de Andalucía. Madrid: Imprenta Real, 1796, t. V.

Palomino, Antonio. El Parnaso Español Pintoresco y Laureado. Madrid: Lucas Antonio de Bedmar, 1724, t. III.

Palomino, Antonio. Vidas. ed. de Nina Ayala MaIlory. Madrid: Alianza, 1986.

Pardo Tomás, José. El libro científico en la República de las Letras. Madrid: CSIC, 2010.

Pemán, César. "La reconstrucción del retablo de la Cartuja de Jerez de la Frontera. Archivo Español de Arte 23/91 (1950): 203-228.

Piveteau, Oliver. Don Miguel Mañara. Frente al mito de Don Juan. Sevilla: Fundación Cajasol, 2007.

Quiles, Fernando. "En los cimientos de la Iglesia sevillana. Fernando III, rey y santo." Bol. del Museo e Instituto Camón Aznar 75-76 (1999): 203-250.

Quiles, Fernando. Teatro de la Gloria. El universo artístico de la Catedral de Sevilla en el Barroco. Sevilla: Diputación, 2007.

Quiles, Fernando. “...Eppur si muove. La pintura sevillana después de la peste negra (16501655)." Anuario del Dpto. de Historia y Teoría del Arte 21 (2009): 193-204.

Quiles, Fernando. “El arzobispo Agustín Spínola, promotor de las artes sevillanas del barroco (1645-1649)." In Génova y la monarquía hispánica (1528-1713), Manuel Herrero Sánchez, Yasmina Rocío Ben Yessef Garfia, Carlo Bitossi, Dino Puncuh, coords., II 731-752. 2011.

Quiles, Fernando. "Sevilla, barroca y renaciente (1649-1675)." In Espacios y muros del barroco iberoamericano, $\mathrm{M}^{\mathrm{a}}$. de los Ángeles Fernández Valle, Carme López Calderón e Inmaculada Rodríguez Moya, eds., 13-37. Sevilla-Santiago: Enredars-Andavira, 2019.

Quiles, Fernando. “Entre mediano y pequeño, entre la capilla y el hogar. Consumo privado de escultura menuda en la Sevilla barroca". En prensa.

Robledo Estaire, Luis. "El sermón como representación: Teatralidad y musicalidad en la oratoria sagrada española de la Contrarreforma." 
Revista de musicología 26/1 (2003): 127-186. https://doi.org/10.2307/20797781

Rodríguez G. de Ceballos, Alfonso. "El 'bel composto' berniniano a la española." Semata. Ciencias sociais e humanidades. Monográfico Cultura, poder e mecenazgo, A. Vigo Trasancos, ed., 10 (1998), 265-279.

Rodríguez G. de Ceballos, Alfonso. "El bel composto berniniano a la española." Figuras e imágenes del Barroco. Estudios sobre el barroco español y sobre la obra de Alonso Cano. Madrid: Argentaria, 1999.

Sánchez-Arjona, José. Noticias referentes a los anales del teatro en Sevilla desde Lope de Rueda hasta fines del siglo XVII. Sevilla: Imprenta de E. Rasco, 1898.

Sánchez Belén, Juan A. "El comercio holandés de las especias en España en la segunda mitad del siglo XVII." HISPANIA. Revista Española de Historia LXX/236 (2010): 633-660. https://doi. org/10.3989/hispania.2010.v70.i236.327

Serrera Contreras, Ramón Ma. "Lope de Vega y 'El Arenal de Sevilla'." Boletín de la Real Aca- demia Sevillana de Buenas Letras: Minervae Baeticae 35 (2007): 149-168.

Serrera Contreras, Ramón Ma. «¿Esplendor o declive?: Sevilla en 1650 y la plata americana." In Redescubriendo el Nuevo Mundo: Estudios americanistas en homenaje a Carmen Gómez, $M^{a}$ Salud Elvás y Sandra Olivero, coords., 1729. Sevilla: Universidad, 2012.

Stein, Stanley J., y Barbara H. Stein. Plata, comercio y guerra: España y Emérica en la formación de la Edad moderna. Barcelona: Crítica, 2002.

Wethey, Harold E. Alonso Cano. Pintor, escultory arquitecto. Madrid: Alianza, 1983.

Wunder, Amanda. "Murillo and the Canonisation Case of San Fernando, 1649-52." The Burlington Magazine 143:1184 (2001): 670-675.

Wunder, Amanda. "Un pintor, un cadáver, y un retratola imaginería de Fernando III en la Sevilla barroca." In Estudios de historia iberoamericana. XXXIII Reunión de la SSPHS, M ${ }^{\text {a Sole- }}$ dad Gómez Navarro y José M. de Bernardo Ares, coords., 128-132. Córdoba: Universidad, 2003. 
